\title{
Phytic Acid: Properties and Potential Applications in Dentistry
}

\begin{abstract}
Mohannad Nassar ${ }^{1 * \dagger}$, Rania Nassar ${ }^{2,3 \dagger}$, Husain Maki ${ }^{4}$, Abdullah Al-Yagoob ${ }^{5}$, Mahmood Hachim ${ }^{2}$, Abiola Senok ${ }^{2}$, David Williams ${ }^{3}$ and Noriko Hiraishi ${ }^{6}$

${ }^{1}$ Department of Preventive and Restorative Dentistry, College of Dental Medicine, University of Sharjah, Sharjah, United Arab Emirates, ${ }^{2}$ College of Medicine, Mohammed Bin Rashid University of Medicine and Health Sciences, Dubai, United Arab Emirates, ${ }^{3}$ Oral and Biomedical Sciences, School of Dentistry, College of Biomedical and Life Sciences, Cardiff University, Cardiff, United Kingdom, ${ }^{4}$ Speciality Dental Residency Program, Ministry of Health, Juffair, Bahrain, ${ }^{5}$ Ras Al Khaimah College of Dental Sciences, Ras Al Khaimah Medical and Health Sciences University, Ras Al Khaimah, United Arab Emirates, ${ }^{6}$ Department of Cariology and Operative Dentistry, Graduate School of Medical and Dental Sciences, Tokyo Medical and Dental University, Tokyo, Japan
\end{abstract}

\section{OPEN ACCESS}

Edited by:

Mary Anne Sampaio Melo,

University of Maryland, Baltimore,

United States

Reviewed by:

Ingrid Mathias-Santamaria,

University of Maryland, Baltimore,

United States

Lamia Mokeem,

University of Maryland, Baltimore, United States

Ivana Vucenik,

Independent Researcher, Baltimore,

$M D$, United States

*Correspondence:

Mohannad Nassar

minassar@sharjah.ac.ae

${ }^{+}$These authors have contributed equally to this work and share first authorship

\footnotetext{
Specialty section

This article was submitted to

Biomaterials,

a section of the journal

Frontiers in Materials
}

Received: 07 December 2020

Accepted: 20 January 2021

Published: 17 March 2021

Citation:

Nassar $M$, Nassar $R$, Maki $H$, Al-Yagoob A, Hachim M, Senok A, Williams D and Hiraishi N (2021) Phytic

Acid: Properties and Potential

Applications in Dentistry.

Front. Mater. 8:638909.

doi: 10.3389/fmats.2021.638909
Inositol hexaphosphate (IP6) is the most abundant inositol phosphate in nature and an essential molecule for different biological functions. IP6 has a unique structure granting it distinctive properties; a high negative charge density provides IP6 with an immense chelating ability and valuable antioxidant properties. IP6 is also simple and cost-effective to produce. These features have attracted researchers and entrepreneurs to further study IP6 for a wide variety of applications in areas such as pharmaceutical, food and chemical industries, medicine, pharmacy, nutrition, and dentistry. The interest in IP6 in the dental field unfolded many decades ago following identification of a cariostatic ability and a positive impact on reducing enamel dissolution. Subsequently, IP6's anti-plaque, anticalculus and cement-forming properties have been investigated. Despite encouraging findings, there was a phase of decreased attention to IP6 which slowed down research progress. However, the potential use of IP6 has recently been revisited through several publications that provided deeper understanding into its mechanisms of action in the aforementioned applications. Studies have also explored new applications in endodontics, adhesive, preventive and regenerative dentistry, and IP6's role in improving the characteristics and performance of dental materials. Evidence of the merits of IP6 in dentistry is now substantial, and this narrative review presents and discusses the different applications proposed in the literature and gives insights of future use of IP6 in the fields of orthodontics, implant and pediatric dentistry.

Keywords: adhesive, application, cariostatic, cement, dentistry, inositol hexakisphosphate, oral, phytic acid

\section{INTRODUCTION}

Phytic acid, known as inositol hexakisphosphate (IP6), inositol polyphosphate, or phytate when in salt form, was first recognized by Pfeffer in 1872 (Pfeffer, 1872), and in 1903 the term "la phytine" was used by Posternak (Posternak, 1903). In 1914, the IP6 structure was described by Anderson (Anderson, 1914) and this was confirmed by Johnson and Tate in 1969 using nuclear magnetic resonance spectroscopy (Johnson and Tate, 1969).

IP6 is a saturated cyclic acid and the phosphate ester of inositol, with the formula $\mathrm{C}_{6} \mathrm{H}_{18} \mathrm{O}_{24} \mathrm{P}_{6}$ (Figure 1). It has a high density of negative charges due to its six phosphate groups that become partially ionized at physiological $\mathrm{pH}$, where the negative charges are counterbalanced by cations, 


\section{$\mathrm{OP}(\mathrm{O})(\mathrm{OH})_{2}$ $(\mathrm{HO})_{2}(\mathrm{O}) \mathrm{PO}$}

FIGURE 1 | Phytic acid structure.

mainly sodium ions. Throughout the present review, IP6 is used to refer to both phytic acid and phytic acid salt "phytate." IP6 is abundant in plants and has a significant nutritional role as the principal storage form of phosphorus in many plant tissues, especially bran and seeds. It is also considered a source of myoinositol, a cell wall precursor (Reddy et al., 1982; Schlemmer et al., 2009). In animal cells, myoinositol polyphosphates are ubiquitous, and IP6 is the most abundant form, with a concentration ranging from 10 to $100 \mu \mathrm{M}$ in mammalian cells, depending on cell type and developmental stage (Szwergold et al., 1987; Sasakawa et al., 1995). The interaction of intracellular IP6 with specific intracellular proteins has been investigated in vitro, and these interactions result in the inhibition or potentiation of the physiological activities of proteins (Norris et al., 1995; Hanakahi et al., 2000). The evidence suggests an intracellular role for IP6 as a cofactor in DNA repair by non-homologous end-joining (Hanakahi et al., 2000). Other studies using yeast mutants, have also suggested that intracellular IP6 may be involved in mRNA export from the nucleus to the cytosol (York et al., 1999; Shears, 2001). IP6 has a potent anti-nutrient ability due to its strong binding affinity to crucial dietary minerals in their elemental form, including calcium, iron, and zinc; thus inhibiting their absorption (Schlemmer et al., 2009; Gupta et al., 2015). Studies have shown that there is a marked decrease of calcium absorption in the presence of IP6 and an enhanced availability after degradation. When iron or zinc binds to IP6, insoluble precipitates form, contributing to deficiencies of these elements in people whose diets rely on foods for their mineral intake (Hunt, 2002; Hurrell, 2003; Kancheva and Kasaikina, 2013). Thus, fortification of food, especially in developed countries, is seen as a desirable measure to achieve the recommended intakes of specific nutrients (FAO/IZiNCG, 2018).

The anti-nutrient effect of IP6 should not negate its health benefits (Nissar et al., 2017), and its ability to form insoluble complexes with calcium might also help decrease bone retention of heavy metals such as lead (Rose and Quarterman, 1984). IP6's strong iron chelating property has been found to have a protective effect in rat neuronal cells against apoptosis in iron-excess conditions, a finding of importance in patients with
Parkinson's disease where disrupted iron homeostasis and iron overload in the brain is evident (Xu et al., 2008).

Studies have also shown that IP6 has an antioxidant effect indicating a role for IP6 in preventing free radical formation through chelation with iron that catalyses the generation of hydroxyl radicals (Graf, 1983; Graf et al., 1987; Graf and Eaton, 1990; Pallauf and Rimbach, 1997; Xu et al., 2008). The protective effect of IP6 against kidney stones and cancer has also been studied (Grases and Costa-Bauza, 1999; Grases et al., 2006; Shafie et al., 2013), and scientists have suggested that IP6 may partly explain why whole grains have been linked with a reduced risk of colon cancer (Aune et al., 2011). IP6's anti-cancer action has been demonstrated both in vitro and in vivo and it is claimed that there is enough evidence to legitimize the start of clinical trials in humans for its use as an anti-neoplastic agent (Fox and Eberl, 2002; Vucenik and Shamsuddin, 2006). IP6 has an inhibitory effect on osteoclastogenesis in human cell lines, suggesting it could play a role in reducing bone-mineral density loss and preventing osteoporosis (López-González et al., 2008; Arriero et al., 2012).

Due to its antioxidant properties, IP6 has been used as a food preservative to prevent spoilage and discoloration (Graf and Eaton, 1990). Adding IP6 to wine and other beverages would reduce the side effects and toxicity of high metal content (e.g. iron) in beverages (Trela, 2010). The pharmaceutical industry has also used IP6, to enhance drug efficacy and reduce undesired side effects. Adding IP6 to the drug content could improve drug absorption and increase oral bioavailability (Xie et al., 2014; Kim et al., 2016).

A finding that might be of interest to dental practitioners is the ability of IP6, in the presence of calcium, to inhibit fluoride bioavailability from the food matrix, thus attenuating the cariespreventive effect of fluoride (Cerklewski, 1992). In dentistry, IP6 gained attention in 1960 when McClure et al. tested its cariostatic effect on rats (McClure, 1960). In 1972, IP6's plaque-inhibiting effectiveness was examined (Nordbö and Rölla, 1972) and in 1975, Cole and Bowen tested its effect on microbial composition of animal dental plaque (Cole and Bowen, 1975). IP6 continued to generate a steady amount of interest due to its ability to bind to hydroxyapatite forming a monomolecular surface layer that limited both the growth and dissolution of hydroxyapatite crystals, thus inhibiting caries, plaque formation and enamel dissolution. These findings led to the development of several patented oral care regimes (Reddy et al., 1982; Graf, 1983; Kaufman, 1986; Sands et al., 1986; Reddy et al., 1989). IP6's cement forming properties were tested by Prosser et al., in 1983 (Prosser et al., 1983) where it was found to produce a fast setting and acid-resistant cement. Although the scholarly interest in IP6 furnished a number of intriguing findings regarding its application in dentistry, this interest reached a hiatus. Recently, interest in IP6 has been revitalized with several research papers exploring potential dental applications including its use in dentifrices and cements, and other new applications such as etchant in adhesive dentistry, chelating agent in endodontics or anti-staining agent added to dentifrices (Nassar et al., 2013; Nassar et al., 2015; Milleman et al., 2018; Parkinson et al., 2018; Uyanik et al., 2019). In 1983, 
Ernst Graf was highly active in researching different features of IP6 and its potential in a vast array of applications. Graf was probably the first to give an in-depth description of the antioxidant and metal chelation properties. He stated that IP6 was an inexpensive, inert, non-toxic and abundant chemical that was easily obtained from different plant sources by relatively simple procedures. Despite all the encouraging data, limited efforts had been given to IP6's application for oral care and he believed that if enough funding and support were secured, novel oral health care products could have been developed (Graf, 1983). Based on the reviewed literature, it seems that IP6 possesses several properties that are valuable across a variety of dental fields. In the last 60 years, the use of IP6 has been evaluated in dentistry; this narrative literature review highlights the major potential applications of IP6 and presents insights into other future applications of this agent in dentistry.

\section{POTENTIAL APPLICATIONS OF IP6 IN DENTISTRY}

\section{Cements}

Dental cements are a mainstay in modern day dentistry where they are used in the restoration of prepared teeth for an indefinite or definite period, depending on the physical characteristics and projected longevity of the restoration (Hill, 2007). The requirements of an ideal cement include, but are not limited to, having sufficient working time and desired physical properties for its intended use, strong enough to resist functional forces and resistant to dissolution upon exposure to the oral environment (de la Macorra and Pradíes, 2002). Dental cements are also important for the success of fixed appliance-based orthodontic therapy, where they are needed to attach bands and brackets to tooth structure along with the ability to protect against dental caries during the treatment period (Millett et al., 2016). Nowadays, several varieties of dental cements are available and the development of new or improved dental cements is still ongoing; however, some have disappeared from the market.

Studies have shown that IP6 can drastically improve both the chemical and physical properties of dental cements when used as an additive. The notion of using IP6 was proposed in 1980, where its addition to aluminosilicate glass, resulted in a rapidly setting cement through an acid-base reaction. The resultant cement had low vulnerability to early attack by water and acid, as well as better adhesion to enamel compared with dentine, due to the lower mineral content of the latter (Prosser et al., 1983). Mechanical properties of zinc phosphate cements also improved with addition of IP6. Increasing the concentration of IP6 from 0 to $2 \%$ doubled the compressive strength. Replacing some of the phosphoric acid with 3-5\% IP6 resulted in maximum compressive strength. When IP6 was added alone, the reaction was rapid and the setting time was short and controllable based on the ratio of IP6 and phosphoric acid or adjusting the water content to attain a more practical setting time. The leach from the resultant cement was reduced when some of the phosphoric acid was replaced with IP6, and this was explained by the higher stability of zinc phytate compared with zinc phosphate. This was considered the main advantage of using IP6. Applications where a large area of cement is exposed to saliva, such as in orthodontics might benefit most from this property. However, at high IP6 concentrations, the resultant cement was too viscous, with a high film thickness, thus rendering the cement unsuitable for dental application (Li et al., 1994).

Calcium silicate-based cements are commonly used in pulpal regeneration and hard tissue repair in endodontics along with mineral trioxide aggregate (MTA) and more recently, with Biodentine $^{\mathrm{TM}}$. MTA exhibits a myriad of drawbacks such as a long setting time, poor handling characteristics and low washout resistance (Dawood et al., 2017). At a certain concentration, IP6 can effectively decrease the setting time of calcium silicate-based cements without altering their diametral tensile strength, and this effect was more pronounced with Biodentine ${ }^{\mathrm{TM}}$ compared with MTA (Uyanik et al., 2019). Acceleration of the setting time could be through the hydrophilic nature of IP6 having a synergistic effect with calcium silicate-based cements, which sets through a hydration reaction. It may also be explained by the highly negatively charged phosphate groups in IP6 that strongly bind to metallic ions within the cements (Hsieh et al., 2009; Silva and Bracarense, 2016). Furthermore, the abundance of negative charges in IP6 could play a role in the reaction process through chelation with calcium in the cement. High water: powder ratio increases porosity and solubility of the cement, thus compromising the mechanical properties of the set material (Li et al., 1994), and this is also applicable to MTA and Biodentine $^{\mathrm{TM}}$ as a high water:powder ratio would adversely affect properties. The use of IP6 is thought to result in less water in the mixed cement; however, no improvement in the diametral tensile strength was detected (Uyanik et al., 2019).

Calcium phosphates occur in different forms, and have found their way into many dental applications, such as preventive dentistry (owing to high resemblance to natural enamel), periodontal therapy, restorative and implant dentistry, and pulp therapy (Al-Sanabani et al., 2013; Meyer et al., 2018). The brushite type of calcium phosphate is considered as a bone replacement material which possesses desirable properties, but also suffers several drawbacks such as short setting times, low mechanical strength and poor injectability, all of which limits the more inclusive clinical application of this cement, and trials to improve these properties are still ongoing (Gbureck et al., 2004). In 2017, Meininger et al. reported that IP6 was a setting retardant of di-calcium phosphate cements, an effect that was necessary to meet the clinical requirements of the handling time of cement that usually sets in less than $1 \mathrm{~min}$ in a retardant-free environment. IP6 is thought to exert this effect by adsorbing at the active growth sites of di-calcium phosphate crystals of the cement, thus delaying the crystal growth rate, which also decreases the maximum setting temperature. In the same study, the highest cement strength values were achieved using citric acid, the most commonly used retarder in brushite cements, followed by IP6, which led to higher values than those obtained with retardant-free cement. These results were correlated with the porosity of the set cement and confirmed some differences in the used retardants regarding the type and phase of the formed crystals in the set material. When IP6 was 
used as a retarder, monetite was the predominant phase formed during setting, whereas citric acid resulted in the formation of a mixture of both brushite and monetite. Interestingly, cements with IP6 showed increased calcium concentration in the medium where the cement samples were immersed, while citric acid containing cement adsorbed calcium ions (Meininger et al., 2017). The increased availability of calcium ions might be advantageous in enhancing dentine formation in exposed dental pulps (Foreman and Barnes, 1990), which has possible implications in the field of regeneration as described later in this review. Cements that contained IP6 had significantly better cytocompatibility towards osteoblast cells compared with citric acid-containing cement (Meininger et al., 2017). In 2018, Hurle et al. studied the effect of IP6 on the hydration mechanism and setting kinetics of brushite cements (Hurle et al., 2018). Their findings were consistent with those obtained by Meininger et al. (Meininger et al., 2017), where controlled concentrations of IP6 acted as a retarder of the cement setting reaction, resulting in better mechanical performance and a cement that was composed of a monetite crystalline structure (Hurle et al., 2018). The latter finding was thought to be of clinical significance as this form of crystalline structure does not undergo phase conversion with aging in phosphate buffered saline (Sheikh et al., 2015). It was also observed that IP6 improved the injectability of the cement, due to the formation of a chelate complex between calcium ions and the phosphate groups of IP6, which led to a delayed rise in paste viscosity and a drastic retarding effect on cement hydration (Hurle et al., 2018). Weichhold et al. found similar effects on apatite cement and concluded that IP6 was a suitable additive for the development of calcium phosphate cement with superior properties (Weichhold et al., 2019).

Glass ionomer cement systems are versatile restorative and luting materials and essential in restorative and pediatric dentistry and orthodontics, because of their fluoride release and chemical adhesion to tooth structure. The literature supports their use in several clinical scenarios. These include cementation of crowns, bridges, inlays, onlays and orthodontic appliances, cavity base or liner, fissure sealant, tooth repair in atraumatic restorative treatment technique and restoration of certain cavity preparations in patients with high-caries risk and teeth that are difficult to isolate (Berg, 2002; Sidhu and Nicholson, 2016). Researchers are constantly striving to improve the performance of these cements as well as to develop new ones. Several chelating additives such as tartaric acid and citric acid have been described in the literature to enhance the characteristics of glass ionomer cements (Sidhu and Nicholson, 2016). It may also be interesting to see future studies on the impact of IP6 on these cements; to the best of our knowledge, such studies have not been performed yet.

\section{Oral Care Products}

Oral care products including dentifrices and mouthrinses are multifunctional, offering an array of advantages to combat an assortment of oral conditions e.g., caries, gingivitis, dentine hypersensitivity, teeth whitening, and halitosis. The addition of chemical agents to conventional products to augment their intended functions such as prevention of caries, plaque inhibition, or stain removal, represents an attractive field of study (Lippert, 2013; Cummins, 2016; Milleman et al., 2018).

Interest in the potential protective effects of different classes of phosphate compounds, including IP6, against caries is not new (Grenby, 1973). The concept of using IP6 as a cariostatic agent probably came from the speculative connection mentioned in earlier studies. These studies revealed an increased caries incidence with decreased intake of IP6 following changes in dietary habits and food processing and refinement (Jenkins et al., 1959a; Jenkins et al., 1959b; Jenkins, 1966). Several early studies showed a reduction of experimental caries in animals fed dietary IP6 (Taketa and Phillips, 1957; Buttner and Muhler, 1959; McClure, 1960; Madsen and Edmonds, 1962; Vogel et al., 1962; McClure, 1963; McClure, 1964; Dawes and Shaw, 1965; Englander and Keyes, 1970; Cole et al., 1980); however, these findings were not corroborated by other researchers, where IP6 had limited or no protective influence (Limbasuta et al., 1961; König and Grenby, 1965; Grenby, 1966; Lllienthal et al., 1966). The cariostatic mechanism of IP6 is not fully understood, although several pathways have been suggested. A local rather than a systemic effect is proposed by most researchers. IP6 rapidly adsorbs to hydroxyapatite forming a monomolecular layer on the crystal surface that leads to increased resistance of enamel to acid attack by acting as a diffusion barrier to ions (Magrill, 1973b) while at the same time limiting the growth of the hydroxyapatite (Koutsoukos et al., 1981; Grases et al., 2015). IP6 is mainly found at the surface of hydroxyapatite but it is too large to diffuse into the hydroxyapatite crystal. Another speculated mechanism is through the formation and precipitation of calcium-IP6 complexes on the crystal surface (Magrill, 1973b). IP6 content on the surface of hydroxyapatite was not significantly affected after washing with water or partial dissolution by acid, which indicated that IP6 was tightly bound to hydroxyapatite surfaces (Magrill, 1973b). The adsorption of IP6 to hydroxyapatite might also cause an alteration of the surface charge and free energy characteristics, thus impeding formation of plaque by negatively influencing the affinity of salivary proteins and bacteria to tooth surfaces (Napper and Smythe, 1966; Grenby, 1967a; Grenby, 1967b; Grenby, 1967c; Kaufman and Kleinberg, 1970; Pruitt et al., 1970; Nordbö and Rölla, 1972; Magrill, 1973b).

Recently, Fernández et al. showed that the adsorption energy to hydroxyapatite was the highest for IP6 when compared with other acids such as pyrophosphate, etidronate, and citrate. IP6 was able to form thirteen electrostatic interactions with hydroxyapatite surfaces. No hydrogen bond interaction was observed between IP6 and hydroxyapatite surfaces; however, the protonated oxygen atoms of IP6 formed hydrogen bonds with contiguous phosphate groups. In their study, there was a positive correlation between the adsorption energy with the number of functional groups and the total molecular negative charge of the acid that interacted with hydroxyapatite surface (Fernández et al., 2017).

The antimicrobial effect of IP6 on cariogenic bacteria is still questionable. However, there is some indication that oral streptococci and lactobacilli are sensitive to IP6 obtained from diet (Grenby, 1967b). There are similar characteristics between IP6 and linear condensed polyphosphates, and thus it might be 
expected that the former may have an inhibitory effect on Streptococcus mutans by modifying certain portions of the glycolytic enzyme system (Handelman and Kreinces, 1973), or chelation of essential metabolites (Post et al., 1963; Elliott et al., 1964; Shibata and Morioka, 1982). Despite the promising potential of IP6 as a cariostatic agent, some researchers cast doubt on the clinical impact of caries control in humans (Grenby, 1967b). Importantly, bacteria with the ability to accumulate polyphosphate intracellularly can alter the chemical conditions of the oral environment and promote caries (Breiland et al., 2018).

Grases et al. showed that a mouthrinse containing IP6 retarded dental calculus formation (Grases et al., 2009). This effect was attributed to IP6 properties in altering protein binding to the tooth surface and concomitantly acting as an inhibitor of hydroxyapatite and brushite crystal formation (Grases et al., 2000). These actions were related to its structural similarity to pyrophosphate, the main polyphosphate used in inhibiting calculus (Cohen et al., 1994). This mechanism has found use in supplemented chewing gums which reduce calculus formation (Porciani et al., 2003). To our knowledge, there are no studies to date on the role of IP6 in chewing gum on removal of teeth stain or inhibition of calculus formation.

Despite these rather equivocal findings, there has been a reasonable endorsement to harness the cariostatic, anti-plaque and anti-calculus properties of IP6 by its inclusion in several oral care products that serve different dental and oral applications such as mouthrinses, dentifrices, dentures cleaners, teeth whitening and stain removal agents, and oral malodor rinses (Graf, 1983; Sands et al., 1986; Garlich et al., 1994; Kleinberg et al., 1998; Hoke et al., 2016; Nakauchi et al., 2017). Milleman et al. evaluated the efficacy of stain removal of $0.85 \%$ w/w IP6 incorporated into an experimental dentifrice, which was better for tooth stain removal than a reference control dentifrice. This provided further evidence that IP6 acted similarly to condensed polyphosphates in augmenting stain removal which was not accompanied with increased abrasivity of the dentifrice. This was considered highly important for people at risk of dentine hypersensitivity. The presence of IP6 in dentifrices is expected to not only remove stain, but also prevent new stain formation, and this effect is thought to be through binding to tooth structure surfaces. This, in turn, would disrupt protein binding to the surfaces through chelating with calcium, thus negatively affecting both the adhesion and the ionic crosslinking of pellicle and stain molecules. The other notable finding in their study was the usefulness of the experimental dentifrice for removing stains from inaccessible and difficult-to-reach areas, and surfaces of teeth that were typically missed during cleaning. The experimental dentifrice was also well-tolerated by the subjects, with no evidence of adverse effects in the oral cavity, at the IP6 level used (Milleman et al., 2018).

A study by Parkinson et al. tested the effect of increasing quantities of IP6 on fluoride ability to promote remineralization. No significant differences were encountered by addition of IP6 at $0.425 \%$ or $0.85 \%$ and there was no attenuation, or improvement in fluoride's caries prevention efficacy. Neither IP6 nor zinc ions within the dose range tested affected fluoride's ability to promote remineralization or prevent demineralization of enamel in the aforementioned model (Parkinson et al., 2018). Additional experiments by Creeth et al. demonstrated that, compared with fluoride-free controls, a dentifrice containing IP6 and sodium fluoride had beneficial effects on the dynamics of remineralization and demineralization for early enamel erosive lesions. However, due to reduced fluoride uptake in the presence of IP6, the remineralizing effect was inhibited. Thus, no benefits for including IP6 were perceived (Creeth et al., 2018), which contrasted with the results of Parkinson et al. (Parkinson et al., 2018). It was stated that this marked contrast was the result of using different models. Creeth et al. used a single-treatment model with plaque-free enamel surfaces (Creeth et al., 2018), whereas Parkinson et al. used plaque-covered surfaces which were clinically more relevant to developing caries lesions (Parkinson et al., 2018). Magrill reported an inhibition of mineralization in enamel specimens pre-treated with IP6 solution. However, the author was not concerned about similar in vivo effects as several animal experiments had already demonstrated the cariostatic properties of IP6 (Magrill, 1973a).

IP6's interaction with cations has received the most attention. However, IP6 also has the ability to interact with enzymes, starch and proteins. These less studied interactions might also be crucial in certain aspects of oral health including dental caries and the longevity of resin-based restorative material in adhesive dentistry, as described later. IP6 interacts with an array of enzymes such as a-amylase (Deshpande and Cheryan, 1984; Knuckles and Betschart, 1987), proteinases (pepsin, trypsin and chymotrypsin) (Singh and Krikorian, 1982; Inagawa, 1987; Deshpande and Damodaran, 1989), lipase (Knuckles, 1988), $\beta$-glucosidases, alcohol dehydrogenase, and polyphenol oxidase (Deshpande, 2002; Du et al., 2012). Interaction with these enzymes results in mostly inhibition of the activity, but some reported no effect or even a positive influence depending on the IP6:enzyme ratio (Deshpande, 2002; Greiner et al., 2006).

Salivary $a$-amylase is one of the major components of saliva and has a variety of biological functions requiring intact enzyme. The ability of salivary $a$-amylase to bind to bacteria leading to clearance might offer a protective effect (Scannapieco et al., 1993). Alternatively, its ability to bind to bacteria and adsorb to tooth enamel (Al-Hashimi and Levine, 1989; Scannapieco et al., 1994), its presence in enamel pellicle (Yao et al., 2001), and its ability to digest starch providing nutrients for cariogenic bacteria point towards a-amylase's role in promoting dental plaque and caries formation (Scannapieco et al., 1993). The inhibitory effect of IP6 on the activity of $\alpha$-amylase is via chelation of calcium (Cawley and Mitchell, 1968), a cation necessary for activation and stabilization of a-amylase (Morris et al., 2011), or through the general complex-forming ability of IP6 with enzyme proteins (Sharma et al., 1978; Deshpande and Cheryan, 1984). Knuckles and Betschart confirmed an inhibitory effect of IP6 on a-amylase's ability to digest starch, and this effect was dependent on the degree of phosphorylation, IP6 concentration, $\mathrm{pH}$ and enzyme source (Knuckles and Betschart, 1987). The inhibitory effect was confirmed in vivo by the inverse relationship between the intake of dietary IP6 and the level of glucose in the blood (Yoon et al., 1983). Meanwhile, 
Björck and Nyman showed IP6 had negligible influence on the activity of $\alpha$-amylase (Björck and Nyman, 1987). The contrasting results reveal the complexity of IP6 interactions and many of the different findings may be due to experimental design, and the fact that in vitro studies may poorly reflect in vivo behaviour of IP6 (Björck and Nyman, 1987).

Starches are one of the predominant dietary carbohydrates in modern societies. The first step in the digestion of starch occurs in the oral cavity by salivary $a$-amylase leading to the formation of oligosaccharides, which may be fermented by oral microorganisms, thus contributing to the caries process (Touger-Decker and van Loveren, 2003; Butterworth et al., 2011). Taking into account the high level of salivary $a$-amylase in humans, Lingström concluded that food starches possess significant cariogenic potential, and it was premature to consider food starches as safe for teeth (Lingström et al., 2000). The authors of a recent systematic review stated that it was the intake of rapidly digestible starches and not total starch intake that was associated with increased risk of caries. As such it is recommended that dental health professionals encourage consumption of food containing slowly digestible starches such as whole grains, fruits, and vegetables (Halvorsrud et al., 2019). Starch digestion is negatively affected by direct IP6 binding with starch via hydrogen bond formation or indirect interaction of IP6 with the proteins (kafirin and glutelin) that bind to starch and are necessary for its digestion, or with $\alpha$-amylase or calcium that is needed for a-amylase activity (Thompson and Yoon, 1984; Rickard and Thompson, 1997; Oatway et al., 2001; Selle et al., 2012). These interactions may modify the substrate leading to compensatory increases in outputs of $\alpha$-amylase in order to digest starch (Selle et al., 2012). Thompson and Yoon studied the in vitro digestion of starch in human saliva. IP6 reduced digestibility by $28 \%$ or $60 \%$ at $1 \mathrm{~h}$ or $5 \mathrm{~h}$ of incubation, respectively (Thompson and Yoon, 1984).

Limited information is available about the in vivo interaction of IP6 with human saliva. In 2019, Delimont et al. were among the first to study salivary protein-IP6 interactions and explore the effect of IP6 supplementation on salivary proteins. In their study, proline-rich proteins did not bind to IP6, whilst IP6 formed weak complexes with a non-enzymatic salivary protein called cystatin SN (Delimont et al., 2019). The effect of IP6 on the functions and properties of cystatin $\mathrm{SN}$ is not yet understood. The main purpose of cystatin SN in the oral environment is inhibition of host cysteine proteases, which are involved in periodontal tissue destruction (Baron et al., 1999) and in protection against dental caries (Vitorino et al., 2006). Cystatin SN also adsorbs to enamel surfaces (Al-Hashimi and Levine, 1989; Johnsson et al., 1991) and has an effect on the sensitivity to bitter taste (Rodrigues et al., 2019). Delimont et al. suggested that repeated IP6 consumption might enhance basic proline-rich proteins production (Delimont et al., 2019), and this represented area of research that needs further exploration as this salivary component comprises about $70 \%$ of the total salivary proteins (Carlson, 1993) and is involved in several important functions that impact the oral health (Bennick, 1982; McArthur et al., 1995). Salivary mucins are glycoproteins that are responsible for several physical and chemical characteristics of mucus and play an important role in lubrication of hard and soft tissues of the oral cavity, modulation of oral microflora and formation of acquired enamel pellicle (Tabak, 1990). IP6 was reported to reduce the adsorption of native human whole salivary mucins to hydroxyapatite by $50 \%$ (Amerongen et al., 1988). However, deglycosylation of mucins increased their ability to compete with IP6 for hydroxyapatite surfaces (Amerongen et al., 1991).

The effect of IP6's interactions with dietary starch, proteins or salivary components such as enzymes on dental caries, pellicle formation and periodontal health is still unclear and the quantity of IP6 available from dietary sources to modify the functions of salivary components is still not known. However, in addition to the previously mentioned cariostatic mechanisms of IP6, we believe that the effect of IP6 on starch digestion and/or amylase activity has a role to play in the perceived anti-caries effect of IP6.

\section{Etching Agent}

Phosphoric acid at a concentration of $37 \%$ has been used in dentistry as an etching agent for enamel (Buonocore, 1955) and for dentine (Fusayama et al., 1979) since 1955 and 1979, respectively. The interaction of the etching agent with dentine is limited by the buffering effect of hydroxyapatite and other dentine components (Wang and Hume, 1988). However, it is believed that the depth of dentine demineralization also directly relates to the concentration of the applied acid (Chiba et al., 1989; Pashley, 1992). The acidic agent removes the smear layer and the superficial part of the dentine, opens the dentinal tubules, demineralizes the dentine surface, and increases the microporosity of the intertubular dentine (Van Meerbeek et al., 1992; Pashley et al., 1993; Sano et al., 1994). Although a definitely more effective enamel bonding is achieved through etching with phosphoric acid (Frankenberger et al., 2008), etching of dentine with phosphoric acid is now considered too aggressive (Van Meerbeek et al., 2011). Application of phosphoric acid to dentine results in exposure of collagen fibrils that are totally devoid of hydroxyapatite (Van Meerbeek et al., 1996; De Munck et al., 2003). These fragile collagen networks are susceptible to collapse, preventing optimal infiltration of resin (Prati et al., 1999; El Feninat et al., 2001), thus resulting in compromised bonding to dentine (Nakajima et al., 2002) and possible postoperative sensitivity (Chersoni et al., 2004). In addition, phosphoric acid regulates the activity of proteolytic enzymes in dentine (Tezvergil-Mutluay et al., 2013; DeVito-Moraes et al., 2016), thus jeopardizing the longevity of resin-based restorative materials (Pashley et al., 2004). Several approaches have been suggested to slow down the enzymatic activity associated with phosphoric acid on dentine, including evaluating other agents to replace phosphoric acid, such as maleic acid, citric acid, lactic acid or ethylenediaminetetraacetic acid (EDTA) (Breschi et al., 2002; Imbery et al., 2012; Trevelin et al., 2019). In addition, the use of crosslinking agents to strengthen the exposed collagen network has been proposed (Macedo et al., 2009).

In 2013, IP6 was evaluated as a dentine etching agent with results showing that upon etching with IP6, the bond strength of resin to dentine was significantly increased compared with phosphoric acid (Nassar et al., 2013). IP6 was shown to 


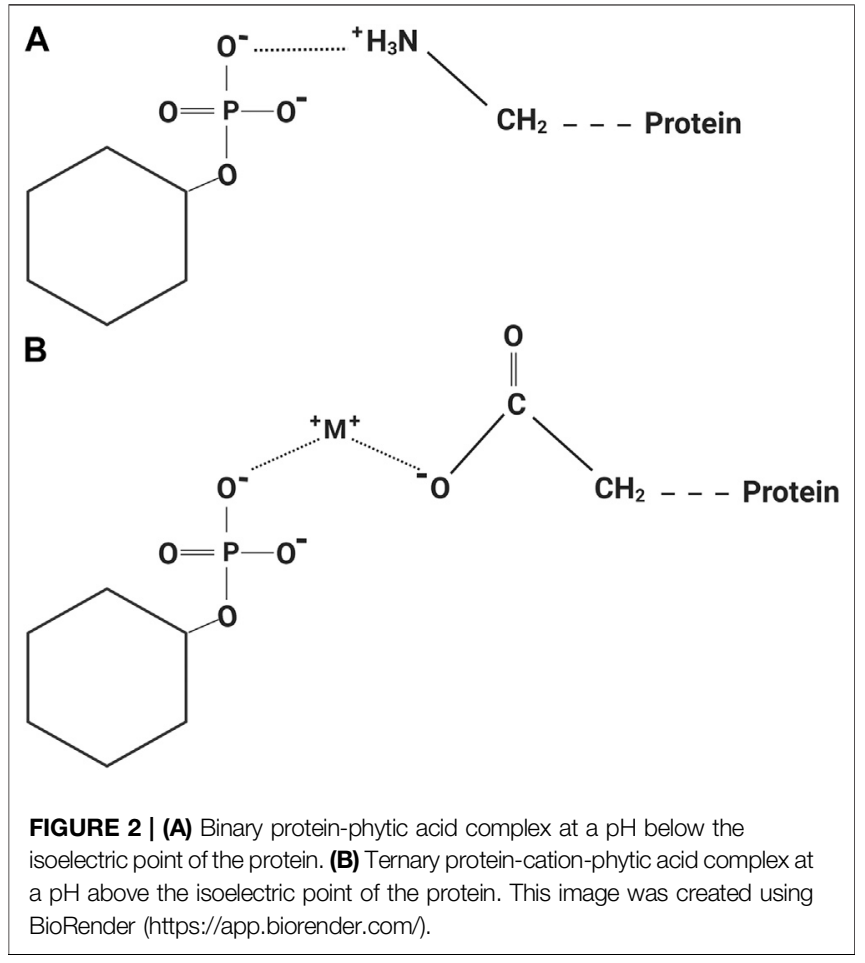

effectively remove the dentinal smear layer at lower concentrations than phosphoric acid, and it also had less adverse effect on pulpal cells (Nassar et al., 2013). The speculated mechanism of action behind the increased resindentine bonding was attributed to two possible events. The first mechanism was due to IP6's ability to form insoluble complexes with calcium at a pH above 4 (Grynspan and Cheryan, 1983). As a result of the high dentine buffering capacity (Camps and Pashley, 2000), the $\mathrm{pH}$ of IP6 increases upon neutralization with dentine, and thus facilitated the formation of the insoluble complex, which might provide a certain level of stability for the exposed collagen. The second speculated mechanism was through the collagen crosslinking action of IP6 (Cheryan and Rackis, 1980; Lee et al., 2011; Ravichandran et al., 2013). The nature of IP6 protein interaction is governed by $\mathrm{pH}$; at a $\mathrm{pH}$ below the isoelectric point of the protein, insoluble binary protein-IP6 complexes (Figure 2A) that dissolve only below $\mathrm{pH} 3.5$ are formed by electrostatic interaction between the anionic phosphate groups of IP6 and the cationic groups of the protein. The binding sites for IP6 within the protein at low $\mathrm{pH}$ are the $\alpha-\mathrm{NH}_{2}$ terminal group, the $\varepsilon-\mathrm{NH}_{2}$ of lysine, the imidazole group of histidine and guanidyl group of arginine. The stability of binary complexes is affected by the competitive action of multivalent cations (Cheryan and Rackis, 1980; Reddy and Salunkhe, 1981; Greiner et al., 2006; Selle et al., 2012). Dentinal collagen has a positive net charge after exposure to acidic solutions (Nezu and Winnik, 2000; Zhang et al., 2005) such as IP6, and thus we assume formation of a binary interaction between IP6 and dentinal collagen occurs. However, this interaction takes a different form at a $\mathrm{pH}$ above the isoelectric point, because both IP6 and the protein have a net negative charge at high $\mathrm{pH}$. A soluble ternary protein-cation-IP6 complex
(Figure 2B) is formed where cations such as calcium, bridges the IP6 to protein. In these types of complexes, the major binding sites are the non-protonated imidazole group of histidine and probably the ionized carboxyl group of the protein. The ternary protein-cation-IP6 complexes may be disrupted by high ionic strength, such as high $\mathrm{pH}(>10)$, and high concentrations of the chelating agents (Cheryan and Rackis, 1980; Reddy and Salunkhe, 1981; Greiner et al., 2006; Selle et al., 2012). Due to the buffering capacity of dentine (Camps and Pashley, 2000), this type of interaction might also occur between IP6 and dentinal collagen. A third more recent mechanism has been proposed for IP6-protein interaction, where IP6 acts as a Hofmeister anion through its six anionic groups that have marked kosmotropic effects resulting in stabilization and reduction of the solubility of proteins by interacting with water in the surrounding medium. However, this mechanism is a new concept that needs further investigation (Selle et al., 2012). Certain IP6-induced protein complexes result in decreased protein solubility and these complexes might be recalcitrant to enzymatic hydrolysis or require higher quantities of the enzymes to be degraded (Ravindran et al., 1995; Selle et al., 2012).

In a study done by Nassar et al., the increased number of mixed mode of failures at the adhesive-resin interface for the IP6etched dentine reflected a strengthening effect of IP6 on the hybrid layer (Nassar et al., 2013). The reduced effect of IP6 on the used pulpal cells compared with phosphoric acid was attributed to the lower concentrations of IP6 used in the study (Nassar et al., 2013) and the ability of IP6 to reduce the level of oxidative stress through chelation with iron. This in turn, inhibits the ability of iron to catalyze the formation of hydroxyl radicals through the Fenton reaction (Xu et al., 2008). It is not only IP6, but also its intermediate products of hydrolysis that have iron chelating properties and are thus still effective in preventing iron ioninduced lipid peroxidation (Miyamoto et al., 2000). The effect of IP6 on dentinal collagen was later confirmed in a study that reported improved ultimate tensile strength of demineralized dentine upon treatment with IP6, which was comparable to results obtained with glutaraldehyde, a gold standard crosslinking agent used in dental research. Dentinal collagen exposed by IP6 was also less susceptible to collapse by airdrying and to collagenase degradation when compared with the fragile network of collagen attained by the use of phosphoric acid (Kong et al., 2015; Kong et al., 2017).

Wang et al. compared the use of IP6, glutaraldehyde and genipin for acellular animal-derived tissue fixation. It was postulated that IP6 with its strong electro-negativity reacts with $-\mathrm{NH}_{2}$ on the tissues to form stable electrovalent bonds that could prevent degradation. To enhance biocompatibility, sodium hydroxide was used to elevate $\mathrm{pH}$, which might also have resulted in the formation of hydrogen bonds between the negatively charged oxygen of phosphate anions and the protons on amino groups. These types of hydrogen bonds were said to far exceed ordinary hydrogen-bond interactions as the oxygen anions of IP6 possessed strong electronegativity, and thus stable fixation was obtained. In their study, 5\% IP6 was used for tissue fixation which resulted in a fixation index of 90\%; no further enhancement occurred when 
$7.5 \%$ or $10 \%$ IP6 was used. The crosslinking rate for glutaraldehyde was quicker than IP6; however, the fixation index was comparable. Genipin had the lowest fixation index and rate. The microscopic porous structure was well preserved after crosslinking with IP6, which was similar to those of natural biological tissues and this intact structure plays an important role in the mechanical support and strength. IP6 resulted in samples with higher ultimate tensile strength compared with controls, indicating more effective crosslinking and formation of a compact intermolecular crosslinking network within collagen fibers. The enzymatic degradation of IP6-fixed tissue by subjecting the samples to collagenase was determined by measuring the relative weight loss of the tissue. At $24 \mathrm{~h}$, control samples were $90.7 \%$ hydrolyzed compared with $49.2 \%$ for IP6-fixed tissues. The authors stated that IP6 introduced stable heteropolar bonds and hydrogen bonds through binding amino group, resulting in obstruction and protection of the cleavage site, blocking the action of the collagenase and reducing tissue degradability. In their study, glutaraldehyde resulted in the least relative weight loss indicating lower tissue degradation compared with IP6 and genipin. However, IP6 was more cytocompatible and enhanced secretion of angiogenic growth factors from human endothelial cells; a result that could increase cell proliferation and attachment and thus the process of angiogenesis (Wang et al., 2017). Tu et al. reported that the effect of IP6 on the self-assembly degree and kinetics of collagen isolated from bovine tendon was dose-dependent. Accelerated self-assembly kinetics and higher self-assembly degree were best at a 1:1 ratio of IP6 to collagen ( $\mathrm{Tu}$ et al., 2018). These findings were attributed to the formation of hydrogen bonding between IP6 and amino group of collagen as described by Wang et al. (Wang et al., 2017). At higher IP6 concentrations, the self-assembly degree and kinetics were negatively affected compared with the control due to occupancy of hydrogen bonding sites on collagen by IP6 and the repulsion between IP6 absorbed on adjacent collagen molecules resulting in an inhibitory effect. The triple-helical conformation of collagen in the presence of IP6 was not altered; however, more slender and thinner morphology of the fibrils was observed than for IP6-free collagen. The thermal stability of collagen fibrils and the viscoelasticity of collagen were also enhanced by IP6 ( $\mathrm{Tu}$ et al., 2018). The results of these studies are not only helpful to design future studies to optimize bonding to dentinal collagen, but they also provide insights into IP6's use in regenerative dentistry, as described later.

Matrix metalloproteinases play an important role in the degradation of the dentine organic matrix, which is mostly composed of collagen, thus leading to failure of resin-dentine bonding (Thompson et al., 2012) or progression of caries process (Toledano et al., 2012). In dentistry, use of matrix metalloproteinases inhibitors has gained much attention as a strategy to improve adhesive bonding to dentine, and currently there is intensive research towards their development (Nassar et al., 2014; Boelen and Boute, 2019). The mechanism of action of the first-generation of matrix metalloproteinases inhibitors is based on zinc and calcium ions chelation (Toledano et al., 2012); these ions are required to maintain optimum tertiary structures and functional active sites of matrix metalloproteinases (Visse and Nagase, 2003). EDTA has a significant inhibitory effect on matrix metalloproteinases through previously described mechanisms; however, EDTA can be rinsed off easily from dentine (Thompson et al., 2012; Toledano et al., 2012). In addition to IP6's excellent ability to chelate with calcium, it is also a potent chelator of zinc. The zincIP6 complex is stable and insoluble (Oatway et al., 2001), and these properties along with an ability to bind to collagen might make IP6 a potential inhibitor of dentinal matrix metalloproteinases.

Despite limited evidence, it seems that controlled concentrations of IP6 are not aggressive to dentine and create a stable collagen network which might be clinically translated to better longevity of resin-based restorations. However, more research is warranted on the effect of IP6 on dentinal matrix metalloproteinases and cysteine cathepsin which play important role in destruction of dentine organic matrix following etching of dentine by acidic agents. We also believe that IP6's interaction with dentinal collagen and metals merits thorough and comprehensive examination, and future studies could be directed to evaluating the stability and enzymatic degradation of IP6-treated dentinal collagen (Forgione et al., 2021).

\section{Chelating Agent}

The success of root canal therapy depends on both mechanical and chemical debridement. Mechanical debridement forms a smear layer inside the canal walls and is often associated with the incomplete seal and lack of adaptation of obturation materials to canal walls. Despite failure of reaching a consensus on whether to remove the smear layer or not, much of the literature seems to promote its removal (Violich and Chandler, 2010). Sodium hypochlorite is the most widely used intra-canal irrigant; however, it fails to fully remove the smear layer, which is the basic rationale behind use of chelating agents in endodontics (Haapasalo et al., 2014). Since 1957, EDTA at a concentration of $17 \%$ and an application time of 1-5 min has been the chemical of choice for smear layer removal (Nygaard-Ostby, 1957; Calt and Serper, 2002). EDTA is overused globally and is a major pollutant (Sillanpää, 1997). Furthermore, EDTA is not readily biodegradable and its extrusion into the periapical tissue needs to be avoided (Amaral et al., 2007). Thus, despite its popularity, a search for other chelating agents is ongoing. Solutions of chitosan, phosphoric acid, citric acid, and MTAD (mixture of doxycycline, citric acid and a detergent) have been studied as smear layer removal agents (Torabinejad et al., 2003; Machado-Silveiro et al., 2004; Prado et al., 2011; Silva et al., 2013). In 2015, Nassar et al. highlighted the potential of IP6 as an alternative root canal chelating agent (Nassar et al., 2015). The mechanism of the chelating action of IP6 stems from its multiple negative charges giving it a high affinity to calcium (Torres et al., 2005). Application of IP6 at concentrations lower than those used for EDTA removes the smear layer and widely opens dentinal tubules, whilst also being biocompatible to osteoblastic cells. The latter finding was based on the results of alkaline phosphatase activity and viability tests, when compared with EDTA, which might be reflected clinically as more rapid 
wound healing in the periapical area in cases of extrusion (Nassar et al., 2015; Nassar et al., 2020). Milder effects on osteoblast cells may be explained by the lower concentration of IP6 needed to remove the inorganic component of the smear layer and its beneficial properties to protect the cells from iron-induced damage as described in the etchant section of this review. Eymirli et al. demonstrated that IP6 and EDTA produced similar results with regard to removing intracanal triple antibiotic paste and calcium hydroxide from root dentine (Eymirli et al., 2017). While Afshan et al. found that 1\% IP6 had reduced erosive potential and smear layer removal ability compared with 17\% EDTA, and this finding was in line with Jagzap et al. (Jagzap et al., 2017; Afshan et al., 2020).

When a new chemical is being evaluated as a smear layer removal agent, it is important to consider its effect on the chemical and physical characteristics of dentine by measurement of dentinal roughness and microhardness. The changes in roughness reflect altered topography and wettability of dentine, which might have an effect on the microbial and dental materials adhesion to dentine (Eick et al., 1972; Attal et al., 1994; Hu et al., 2010; Xu et al., 2019). A change in microhardness denotes an effect on the mineral content of dentine represented mainly by the calcium:phosphorus ratio (Hennequin et al., 1994; Doğan and Çalt, 2001). Decreased microhardness assists mechanical instrumentation of the canals (Cruz-Filho et al., 2002); however, a disproportionately heavy demineralization might weaken the tooth structure (Ulusoy and Görgül, 2013) and create a fragile collagen network which is susceptible to collapse, resulting in insufficient penetration of the adhesive or sealer, and suboptimal sealing ability (García-Godoy et al., 2005). The effect of IP6 on dentine roughness and microhardness has recently been studied and compared with EDTA. Nikhil et al. reported a higher reduction in dentine microhardness with $17 \%$ EDTA compared with 1\% IP6, while, Muana et al., showed that $1 \%$ IP6 resulted in significantly higher roughness and lower microhardness compared with 17\% EDTA (Nikhil et al., 2016; Muana et al., 2020). The equivocal results from studies comparing EDTA and IP6 on their effects on the smear layer, dentine microhardness and roughness, may be attributed to differences in $\mathrm{pH}$, exposure time, and method of application of the tested agents (Muana et al., 2020). In addition, though IP6 is often solely referred to as IP6, commercial products of this solution often contain considerable amounts of impurities in the form of inositol with lesser degrees of phosphorylation, such as IP2, IP3, IP4, and IP5, and free orthophosphate. This will lead to different degrees of phosphorylation of the available products in the market (Hoke et al., 2016). The lower forms of IP6 are known to have reduced metal binding capacity (Persson et al., 1998), which is a function of the number of phosphate groups on the myo-inositol ring. The cation-myo-inositol phosphate complexes are also more soluble as the number of phosphate groups decreases (Greiner et al., 2006).

A characteristic of chelating agents is the ability to eradicate bacteria. Enterococcus faecalis is the most common microorganism associated with endodontic failure and persistent infections, and is known for its ability to resist several antibacterial agents (Stuart et al., 2006). The effect of IP6 on E. faecalis was recently assessed, where IP6 was found to be both bacteriostatic and bactericidal. The minimum inhibitory concentration (MIC) of IP6 was $0.156 \%$ while the minimum bactericidal concentration was $0.625 \%$. In the same study, the MIC of EDTA was 0.14\%; however, EDTA did not exhibit bactericidal activity. Further studies are needed to fully comprehend the mechanism of action of IP6 against endodontic pathogens (Nassar and Nassar, 2017). In general, the antimicrobial effect of IP6 has not been widely studied. Kim and Rhee stated that IP6's antimicrobial activity was expected to be different than the mechanism for other organic acids, which is the weak acid theory, and this is attributed to the unique structure of IP6 and its wide acidity range (Kim and Rhee, 2016). IP6 was found to be effective against some Gram-positive and Gramnegative bacteria (Zhou et al., 2019), and the proposed mechanism was by its chelating ability and cell membrane disruption (Kim and Rhee, 2016), thus causing excessive cell permeability, changes in cell morphology and reduction in intracellular ATP concentration (Zhou et al., 2019).

\section{Implantology}

Implantology is a rapidly growing dental field, where research aims to produce implants with superior properties (He et al., 2019). Osseointegration is the target of the implant industry, which is constantly modifying dental implant surfaces for improved direct structural and functional connection between the bone and the surface of the implant. The implant surface morphology, composition and the interaction with the surrounding tissues play key roles on the outcome of osseointegration (Bowers et al., 1992; Martin et al., 1995; Cochran et al., 1998; Petö et al., 2002). Conventionally, phosphoric acid has been used to treat the implant surfaces prior to its placement to increase surface porosity to promote healing and attachment (França et al., 2018). The use of chemical agents such as phosphoric acid is considered an integral part in the protocol of decontamination of implant surfaces during surgical peri-implantitis treatment (Hentenaar et al., 2017).

Recent studies tested IP6 as an alternative to conventional surface treating agents. Titanium surfaces can be covalently functionalized with IP6 through the direct reaction of phosphate groups of IP6 with titanium oxide without the need for a crosslinker. The resulting bioactive functionalized surfaces had an osteogenic effect that is thought to result in reduced progression of bone resorption and enhancement of osseointegration. There was also decreased adhesion of bacterial biofilm to the treated surfaces (Córdoba et al., 2016).

The success of dental implants is a function of several parameters, and the titanium oxide layer on the implant surface is one of them. Thus, several reports have sought to modify this oxide layer to enhance biological performance and attain best clinical results (Palmquist et al., 2010; de Souza et al., 2019; He et al., 2019). Use of IP6 to modify the titanium oxide layer was studied by Zhang et al. In their research, the liquid phase deposition of this layer was assisted by using an IP6 template that stimulated nucleation and promoted titanium oxide development, leading to a homogeneous and compact 
film that displayed a notable hydrophilic behaviour and excellent bending strength (Zhang et al., 2016). Due to the chemical structure and properties of IP6, it is thought that IP6 can serve as a bridge between the titanium implant surfaces and calcium ions. This was the basis of the study conducted by Liu et al. in 2019, where calcium was successfully bound to implant surfaces via hydrothermal treatment with IP6 and this resulted in a continuous release of calcium over time. The research also reported the super-hydrophilicity of these modified surfaces, with increased cell adhesion and proliferation, and up-regulation of osteogenic-related genes (Liu et al., 2019).

Hydroxyapatite coatings have received a lot of attention from the dental implant industry as they are thought to facilitate an osteoconductive effect. However, enhanced susceptibility of hydroxyapatite to bacterial activity is a major concern (Pajor et al., 2019). To overcome this drawback, IP6 was used to incorporate ionic sliver into a hydroxyapatite coating using a low heat immersion process, thus granting the coating an antibacterial feature (Funao et al., 2016). A magnesium ionintegrated IP6 coating was also developed for improved corrosion resistance, reduced degradation rate and to heighten the osteocompatibility (Chen et al., 2014). Collectively, these findings might direct researchers' attention towards the use of IP6 to produce implants with superior quality and enhanced long-term clinical outcomes.

\section{Regeneration}

The potential for regenerative therapy in endodontics is rapidly gaining attention. The principle aim is to restore and maintain tooth vitality through biologically based procedures designed to replace damaged tooth structure such as dentine and the pulpdentine complex (Murray et al., 2007; Kim et al., 2018). Both pulp and dentine play crucial roles in regenerative endodontics. The former has a population of dental stem cells with inherent differential propensity, which gives the pulp its regenerative capacity (Sloan and Smith, 2007; Govindasamy et al., 2010). The dentine matrix is a source of bio-active dentine matrix components that get released following tissue injury. Several bioactive molecules have been identified in dentine such bone morphogenetic proteins and growth factors, which are essential for the regenerative process (Cassidy et al., 1997; Smith, 2003; Mazzoni et al., 2015). Endodontic irrigants and materials have been used to induce release of dentine-bound bioactive molecules during regenerative procedures (Graham et al., 2006; Tomson et al., 2007; Galler et al., 2016; Smith et al., 2016; Alghilan et al., 2017). EDTA as an irrigant has gained particular attention and is considered the gold standard in regenerative endodontics (Duncan et al., 2018; Atesci et al., 2020) due to its ability to demineralize dentine and release growth factors from the dentine matrix (Yamauchi et al., 2011; Galler et al., 2015; Galler et al., 2016). EDTA also has a positive influence on dental pulp stem cell adhesion, their migration to dentinal walls, and differentiation to odontoblast-like cells (Sonoyama et al., 2008; Galler et al., 2016). Equivalent studies using IP6 are limited. In 2018, Deniz Sungur et al. compared the effect of 1\% IP6, 17\% EDTA and 9\% etidronic acid on growth factor release, and dental pulp stem cell migration and viability. IP6 was found to promote release of transforming growth factor (TGF- $\beta$ ), which in turn influenced cellular activity and increased pulpal cell migration and proliferation. The amount of release was lower than for EDTA or etidronic acid. However, the differences were not statistically significant. Furthermore, EDTA and IP6 resulted in similar migration and proliferation of the cells after $24 \mathrm{~h}$ exposure. However, at this exposure time, EDTA resulted in a contracted and spherical morphology, while IP6-treated cells displayed a polygonal morphology that was more stretched out onto the dentine surface (Deniz Sungur et al., 2019). Recently, Atesci et al. studied the effect of 17\% EDTA and 1\% IP6 on the release of different types of growth factors and mesenchymal stem cell behaviour (Atesci et al., 2020). No adverse impacts of these agents on stem cell proliferation and attachment to root dentine were demonstrated. The amount of TGF- $\beta$ or vascular endothelial growth factor released with either EDTA or IP6 was statistically similar. IP6 showed the highest release of bone morphogenetic protein 2 and fibroblast growth factor 2 in cellfree solutions that contained dentine discs. However, the difference did not reach the level of significance compared to EDTA (Atesci et al., 2020).

Bioactive glasses are involved in the regeneration of dental hard tissues through two different processes, namely in situ remineralization of enamel and dentine, and inducing odontogenic differentiation of dental pulp cells leading to tertiary dentine formation (Mocquot et al., 2020). The need for a bioactive glass with superior bioactivity and biodegradability has led to the use of IP6. The structure of IP6 and its extensive phosphorus component confer an ability to be a good candidate for the synthesis of bioactive glass with high phosphate content. Modifying the phosphate content allowed production of bioactive materials with bioactivity over a wider composition range and different degradation rates that suit the intended application. The bioactive glasses derived from IP6 also showed improved resistance to dissolution compared with other phosphorus precursors, and absence of calcium nitrate, a toxic material, thus expanding its application range. In the presence of IP6, calcium ions incorporate within the gel network without the need of further calcination treatments at higher temperature ( $\mathrm{Li}$ and Qiu, 2011). Ren et al. compared the effect of three different phosphorus precursors on the bioactivity and structure of bioactive glass. It was found that the material prepared with IP6 remained amorphous with more phosphorus atoms present as orthophosphate, and also had more bioactivity compared with other phosphorus precursors (Ren et al., 2017).

In 2017, Cui et al. compared the effect of IP6-derived bioactive glass (PSC) and traditional bioactive glasses on the differentiation of dental pulp cells and formation of dentine. PSC promoted earlier hydroxycarbonate apatite precipitation, which could be of a clinical importance in establishing a rapid bond between the bioactive material and the soft and hard tissues of the pulpdentine complex. This in turn would enhance regeneration and repair of the complex. PSC also exhibited better biocompatibility as it provided a stable $\mathrm{pH}$ and protected the pulpal cells from severe inflammation. The larger surface area of PSC resulted in the release of higher amounts of phosphorus and silicon which led to more effective cell proliferation and odontogenic 
TABLE 1 | Summary of the potential applications of IP6 and the perceived benefits in dentistry.

\begin{tabular}{|c|c|}
\hline $\begin{array}{l}\text { IP6 potential dental } \\
\text { application }\end{array}$ & Perceived benefits \\
\hline Cement & $\begin{array}{l}\text { Improving the chemical and physical characteristics of cements used in several applications in restorative, adhesive, } \\
\text { preventive and pediatric dentistry, orthodontics and endodontics }\end{array}$ \\
\hline Oral care products & $\begin{array}{l}\text { Developing new oral care products and improving the efficiency of professionally applied or patient-applied products such } \\
\text { as varnishes, mouthrinses, dentifrices, whitening products and chewing gum used for their cariostatic, anti-calculus, anti- } \\
\text { plaque, anti-stain and anti-microbial effects }\end{array}$ \\
\hline Etching agent & $\begin{array}{l}\text { Used as an alternative to phosphoric acid to extend the longevity of restorations, enhance resin bonding to tooth structure, } \\
\text { improve biocompatibility to pulpal cells and decrease post-operative sensitivity }\end{array}$ \\
\hline Chelating agent & $\begin{array}{l}\text { Used in root canal treatment to overcome drawbacks associated with EDTA, improve biocompatibility to osteoblast cells, } \\
\text { enhance adhesion to root canal dentine and offer antimicrobial properties }\end{array}$ \\
\hline Implantology & $\begin{array}{l}\text { Used as implant surface treating agent to create a bioactive surface with enhanced osseointegration and decreased biofilm } \\
\text { adhesion }\end{array}$ \\
\hline Regeneration & $\begin{array}{l}\text { Improving bioactivity, biocompatibility and chemical and physical characteristics of scaffolds and cements used in tissue } \\
\text { regeneration and repair. Used in regenerative endodontics to release growth factors from root canal dentine }\end{array}$ \\
\hline
\end{tabular}

differentiation. Differences in up-regulation of certain genes for the bioactive materials were found to affect the quality of the formed dentine. Reparative dentine stimulated by PSC was found to be thicker and formed in a continuous layer of dentine-like tissue with well-organized dentinal tubules (Cui et al., 2017). PSC has been also used to improve the mechanical performance and bioactivity of poly (1,8-octanediol-co-citrate). The latter is a synthetic biodegradable polyester used for soft tissue engineering. However, it lacks certain properties, thus limiting its application in bone regeneration. Poly (1,8-octanediol-co-citrate) composited with PSC exhibits higher mechanical strength, bioactivity, and biocompatibility with a reduced degradation rate. It also integrated well with the surrounding tissues which would result in better bone regeneration (Ren et al., 2017). PSC/bioactive bone cement composite also showed improved injectability and maintained its shape which made it easier to manipulate during the operation (Zhu et al., 2017). A patent describing PSC-polymer bone scaffold has been recently disclosed in 2019 (Deng et al., 2019). The effect of IP6 on the characteristics of polyelectrolyte hydrogel, a tissue engineering scaffold, was studied. It was concluded that IP6 produced a hydrogel scaffold with improved mechanical properties and antimicrobial capability (Bui and Huang, 2019). Several other researchers reported enhanced characteristics of biocements with the use of IP6; however, its effect on the setting time is dependent on several factors that are beyond the scope of this review (Horiguchi et al., 2008; Konishi et al., 2012; Christel et al., 2015; Medvecky et al., 2020).

IP6 has the potential to be used in regenerative dentistry. However, further studies are needed with regard to verifying this aspect of its use (Cui et al., 2017). Collectively, the previously mentioned findings do not capture the various aspects needed

\section{REFERENCES}

Afshan, Z., Jat, S. A., Khan, J. A., Hasan, A., and Rehman Qazi, F. U. (2020). Erosive potential of $1 \%$ phytic acid on radicular dentine at different time intervals. Eur. Endod. J. 5, 28-34. doi:10.14744/eej.2019.02411

Al-Hashimi, I., and Levine, M. J. (1989). Characterization of in vivo salivaryderived enamel pellicle. Arch. Oral Biol. 34, 289-295. doi:10.1016/00039969(89)90070-8 when evaluating an emerging agent in the field of regeneration. Consequently, we believe that these studies serve the same fundamental objective, which is to provide guidance about future research ideas on the use of IP6 in regenerative dentistry.

\section{CONCLUSIONS AND FUTURE DIRECTIONS}

IP6 is a versatile agent that lends itself to the development of new oral care products and the improvement of currently available materials in a variety of applications in the field of dentistry (Table 1). Most IP6-related research is still in its infancy, and in experimental stages at best, though its uniqueness and importance for several potential dental applications had been recognized early. However, in recent years, novel and rather compelling experimental data have been produced. The evidence for use of IP6 in dentistry is growing and the results are too compelling to be ignored. However, there are several limitations within the available literature, which demand calls for further rigorous research approaches towards clinical studies to further augment this evidence. Consideration of some of the recommendations and suggested future studies described in this review paper could facilitate more efficient use of IP6 in several facets of dentistry.

\section{AUTHOR CONTRIBUTIONS}

All authors listed have made a substantial, direct, and intellectual contribution to the work and approved it for publication.

Al-Sanabani, J. S., Madfa, A. A., and Al-Sanabani, F. A. (2013). Application of calcium phosphate materials in dentistry. Int. J. Biomater. 2013, 876132. doi:10. $1155 / 2013 / 876132$

Alghilan, M. A., Windsor, L. J., Palasuk, J., and Yassen, G. H. (2017). Attachment and proliferation of dental pulp stem cells on dentine treated with different regenerative endodontic protocols. Int. Endod. J. 50, 667-675. doi:10. $1111 /$ iej.12669

Amaral, K. F., Rogero, M. M., Fock, R. A., Borelli, P., and Gavini, G. (2007). Cytotoxicity analysis of EDTA and citric acid applied on murine resident 
macrophages culture. Int. Endod. J. 40, 338-343. doi:10.1111/j.1365-2591.2007. 01220.x

Amerongen, A. V. N., Oderkerk, C. H., and Veerman, E. C. (1991). Adsorption to hydroxyapatite of partially deglycosylated human salivary mucins in competition with phosvitin and phytate. Biol. Chem. Hoppe. Seyler. 372, 585-591. doi:10.1515/bchm3.1991.372.2.585

Amerongen, N. A. V, Oderkerk, C. H., and Veerman, E. C. (1988). Influence of phytate on the adsorption of human salivary mucins onto hydroxyapatite. J. Biol. Buccale. 16, 203-208.

Anderson, R. J. (1914). A contribution to the chemistry of phytin. J. Biol. Chem. 17, 171-190. doi:10.1016/s0021-9258(18)88416-2

Arriero, M. d. M., Ramis, J. M., Perelló, M., and Monjo, M. (2012). Inositol hexakisphosphate inhibits osteoclastogenesis on RAW 264.7 cells and human primary osteoclasts. PLoS One. 7, e43187. doi:10.1371/journal. pone. 0043187

Atesci, A. A., Avci, C. B., Tuglu, M. I., Ozates Ay, N. P., and Eronat, A. C. (2020). Effect of different dentin conditioning agents on growth factor release, mesenchymal stem cell attachment and morphology. J. Endod. 46, 200-208. doi:10.1016/j.joen.2019.10.033

Attal, J. P., Asmussen, E., and Degrange, M. (1994). Effects of surface treatment on the free surface energy of dentin. Dent. Mater. 10, 259-264. doi:10.1016/01095641(94)90071-x

Aune, D., Chan, D. S., Lau, R., Vieira, R., Greenwood, D. C., Kampman, E., et al. (2011). Dietary fibre, whole grains, and risk of colorectal cancer: systematic review and dose-response meta-analysis of prospective studies. BMJ 343, d6617. doi:10.1136/bmj.d6617

Baron, A., DeCarlo, A., and Featherstone, J. (1999). Functional aspects of the human salivary cystatins in the oral environment. Oral Dis. 5, 234-240. doi:10. 1111/j.1601-0825.1999.tb00307.x

Bennick, A. (1982). Salivary proline-rich proteins. Mol. Cel. Biochem. 45, 83-99. doi:10.1007/BF00223503

Berg, J. H. (2002). Glass ionomer cements. Pediatr. Dent. 24, 430-438.

Björck, I. M., and Nyman, M. E. (1987). In vitro effects of phytic acid and polyphenols on starch digestion and fiber degradation. J. Food Sci. 52, 1588-1594. doi:10.1111/j.1365-2621.1987.tb05885.x

Boelen, G.J., Boute, L., d'Hoop, J., EzEldeen, M., Lambrichts, I., and Opdenakker, G. (2019). Matrix metalloproteinases and inhibitors in dentistry. Clin. Oral Invest. 23, 2823-2835. doi:10.1007/s00784-019-02915-y

Bowers, K. T., Keller, J. C., Randolph, B. A., Wick, D. G., and Michaels, C. M. (1992). Optimization of surface micromorphology for enhanced osteoblast responses in vitro. Int. J. Oral Maxillofac. Implants 7, 302-310.

Breiland, A. A., Flood, B. E., Nikrad, J., Bakarich, J., Husman, M., Rhee, T., et al. (2018). Polyphosphate-accumulating bacteria: potential contributors to mineral dissolution in the oral cavity. Appl. Environ. Microbiol. 84, e02440-17. doi:10. 1128/AEM.02440-17

Breschi, L., Gobbi, P., Mazzotti, G., Falconi, M., Ellis, T. H., and Stangel, I. (2002). High resolution SEM evaluation of dentin etched with maleic and citric acid. Dent. Mater. 18, 26-35. doi:10.1016/s0109-5641(01)00017-3

Bui, H. L., and Huang, C. J. (2019). Tough polyelectrolyte hydrogels with antimicrobial property via incorporation of natural multivalent phytic acid. Polymers 11, 1721. doi:10.3390/polym11101721

Buonocore, M. G. (1955). A simple method of increasing the adhesion of acrylic filling materials to enamel surfaces. J. Dent. Res. 34, 849-853. doi:10.1177/ 00220345550340060801

Butterworth, P. J., Warren, F. J., and Ellis, P. R. (2011). Human $\alpha$-amylase and starch digestion: an interesting marriage. Starch/Stärke 63, 395-405. doi:10. 1002/star.201000150

Buttner, W., and Muhler, J. C. (1959). The effect of oat hulls on the dental caries experience in rats. J. Dent. Res. 38, 823-824. doi:10.1177/ 00220345590380041001

Calt, S., and Serper, A. (2002). Time-dependent effects of EDTA on dentin structures. J. Endod. 28, 17-19. doi:10.1097/00004770-200201000-00004

Camps, J., and Pashley, D. H. (2000). Buffering action of human dentin in vitro. J. Adhes. Dent. 2, 39-50.

Carlson, D. M. (1993). Salivary proline-rich proteins: biochemistry, molecular biology, and regulation of expression. Crit. Rev. Oral Biol. Med. 4, 495-502. doi:10.1177/10454411930040033401
Cassidy, N., Fahey, M., Prime, S. S., and Smith, A. J. (1997). Comparative analysis of transforming growth factor-beta isoforms 1-3 in human and rabbit dentine matrices. Arch. Oral Biol. 42, 219-223. doi:10.1016/S0003-9969(96)00115-X

Cawley, R. W., and Mitchell, T. A. (1968). Inhibition of wheat $\alpha$-amylase by bran phytic acid. J. Sci. Food Agric. 19, 106-108. doi:10.1002/jsfa.2740190210

Cerklewski, F. L. (1992). Phytic acid plus supplemental calcium, but not phytic acid alone, decreases fluoride bioavailability in the rat. J. Nutr. Biochem. 3, 87-90. doi:10.1016/0955-2863(92)90097-3

Chen, Y., Zhao, S., Liu, B., Chen, M., Mao, J., He, H., et al. (2014). Corrosioncontrolling and osteo-compatible $\mathrm{Mg}$ ion-integrated phytic acid (Mg-PA) coating on magnesium substrate for biodegradable implants application. ACS Appl. Mater. Inter. 6, 19531-19543. doi:10.1021/am506741d

Chersoni, S., Suppa, P., Breschi, L., Ferrari, M., Tay, F. R., Pashley, D. H., et al. (2004). Water movement in the hybrid layer after different dentin treatments. Dent. Mater. 20, 796-803. doi:10.1016/j.dental.2003.11.010

Cheryan, M., and Rackis, J. J. (1980). Phytic acid interactions in food systems. Crit. Rev. Food Sci. Nutr. 13, 297-335. doi:10.1080/10408398009527293

Chiba, M., Itoh, K., and Wakumoto, S. (1989). Effect of dentin cleansers on the bonding efficacy of dentin adhesive. Dent. Mater. J. 8, 76-85. doi:10.4012/dmj.8.76

Christel, T., Christ, S., Barralet, J. E., Groll, J., and Gbureck, U. (2015). Chelate bonding mechanism in a novel magnesium phosphate bone cement. J. Am. Ceram. Soc. 98, 694-697. doi:10.1111/jace.13491

Cochran, D. L., Schenk, R. K., Lussi, A., Higginbottom, F. L., and Buser, D. (1998). Bone response to unloaded and loaded titanium implants with a sandblasted and acid-etched surface: a histometric study in the canine mandible. J. Biomed. Mater. Res. 40, 1-11. doi:10.1002/(sici)1097-4636(199804)40:1<1::aid-jbm1>3. $0 . \mathrm{co} ; 2-\mathrm{q}$

Cohen, S., Schiff, T., McCool, J., Volpe, A., and Petrone, M. E. (1994). Anticalculus efficacy of a dentifrice containing potassium nitrate, soluble pyrophosphate, PVM/MA copolymer, and sodium fluoride in a silica base: a twelve-week clinical study. J. Clin. Dent. 5, 93-96.

Cole, M. F., and Bowen, W. H. (1975). Effect of sodium phytate on the chemical and microbial composition of dental plaque in the monkey (Macaca fascicularis). J. Dent. Res. 54, 449-457. doi:10.1177/00220345750540030601

Cole, M. F., Eastoe, J. E., Curtis, M. A., Korts, D. C., and Bowen, W. H. (1980). Effects of pyridoxine, phytate and invert sugar on plaque composition and caries activity in the monkey (Macaca fascicularis). Caries Res. 14, 1-15. doi:10. $1159 / 000260428$

Córdoba, A., Hierro-Oliva, M., Pacha-Olivenza, M. Á., Fernández-Calderón, M. C., Perelló, J., Isern, B., et al. (2016). Direct covalent grafting of phytate to titanium surfaces through Ti-O-P bonding shows bone stimulating surface properties and decreased bacterial adhesion. ACS Appl. Mater. Inter. 8, 11326-11335. doi:10.1021/acsami.6b02533

Creeth, J. E., Parkinson, C. R., Burnett, G. R., Sanyal, S., Lippert, F., Zero, D. T., et al. (2018). Effects of a sodium fluoride- and phytate-containing dentifrice on remineralisation of enamel erosive lesions-an in situ randomised clinical study. Clin. Oral Investig. 22, 2543-2552. doi:10.1007/s00784-018-2351-z

Cruz-Filho, A. M., Paula, E. A., Pécora, J. D., and Sousa-Neto, M. D. (2002). Effect of different EGTA concentrations on dentin microhardness. Braz. Dent. J. 13, 188-190. doi:10.1590/s0103-64402002000300009

Cui, C. Y., Wang, S. N., Ren, H. H., Li, A. L., Qiu, D., Gan, Y. H., et al. (2017). Regeneration of dental-pulp complex-like tissue using phytic acid derived bioactive glasses. RSC Adv. 7, 22063-22070. doi:10.1039/c7ra01480e

Cummins, D. (2016). The superior anti-caries efficacy of fluoride toothpaste containing 1.5\% arginine. J. Clin. Dent. 27, 27-38.

Dawes, C., and Shaw, J. H. (1965). Dietary phosphate supplementation and its effects on dental caries and salivary and serum concentrations of calcium and inorganic phosphate in the rat. Arch. Oral Biol. 10, 567-577. doi:10.1016/00039969(65)90002-6

Dawood, A. E., Parashos, P., Wong, R. H. K., Reynolds, E. C., and Manton, D. J. (2017). Calcium silicate-based cements: composition, properties, and clinical applications. J. Investig. Clin. Dent. 8, e12195. doi:10.1111/jicd.12195

de la Macorra, J. C., and Pradíes, G. (2002). Conventional and adhesive luting cements. Clin. Oral Investig. 6, 198-204. doi:10.1007/s00784-002-0184-1

De Munck, J., Van Meerbeek, B., Yoshida, Y., Inoue, S., Vargas, M., Suzuki, K., et al. (2003). Four-year water degradation of total-etch adhesives bonded to dentin. J. Dent. Res. 82, 136-140. doi:10.1177/154405910308200212 
de Souza, V. Z., Joly, J. C., Elias, C. N., Peruzzo, D. C., Napimoga, M. H., et al. (2019). Viability and collagen secretion by fibroblasts on titanium surfaces with different acid-etching protocols. Int. J. Implant Dent. 5, 41. doi:10.1186/s40729019-0192-4

Delimont, N. M., Katz, B. B., Fiorentino, N. M., Kimmel, K. A., Haub, M. D., Rosenkranz, S. K., et al. (2019). Salivary cystatin SN binds to phytic acid in vitro and is a predictor of nonheme iron bioavailability with phytic acid supplementation in a proof of concept pilot study. Curr. Dev. Nutr. 3, Nzz057. doi:10.1093/cdn/nzz057

Deng, M., Qiu, D., and Zuponcic, J. L. (2019). Bioactive glass-polymer composite bone scaffolds. Google Patents US-2019134262-A1

Deniz Sungur, D., Aksel, H., Ozturk, S., Yllmaz, Z., and Ulubayram, K. (2019). Effect of dentine conditioning with phytic acid or etidronic acid on growth factor release, dental pulp stem cell migration and viability. Int. Endod. J. 52, 838-846. doi:10.1111/iej.13066

Deshpande, S. S. (2002). Handbook of food toxicology. Boca Raton, FL: CRC Press.

Deshpande, S. S., and Cheryan, M. (1984). Effects of phytic acid, divalent cations, and their interactions on a-Amylase activity. J. Food Sci. 49, 516-519. doi:10. 1111/j.1365-2621.1984.tb12456.x

Deshpande, S. S., and Damodaran, S. (1989). Effect of phytate on solubility, activity and conformation of trypsin and chymotrypsin. J. Food Sci. 54, 695-699. doi:10. 1111/j.1365-2621.1989.tb04684.x

DeVito-Moraes, A., Francci, C., Vidal, C. M., Scaffa, P. M., Nesadal, D., Yamasaki, L. C., et al. (2016). Phosphoric acid concentration affects dentinal MMPs activity. J. Dent. 53, 30-37. doi:10.1016/j.jdent.2016.06.002

Doğan, H., and Qalt, S. (2001). Effects of chelating agents and sodium hypochlorite on mineral content of root dentin. J. Endod. 27, 578-580. doi:10.1097/ 00004770-200109000-00006

Du, Y., Dou, S., and Wu, S. (2012). Efficacy of phytic acid as an inhibitor of enzymatic and non-enzymatic browning in apple juice. Food Chem. 135, 580-582. doi:10.1016/j.foodchem.2012.04.131

Duncan, H. F., Kobayashi, Y., and Shimizu, E. (2018). Growth factors and cell homing in dental tissue regeneration. Curr. Oral Health Rep. 5, 276-285. doi:10. 1007/s40496-018-0194-y

Eick, J. D., Johnson, L. N., Fromer, J. R., Good, R. J., and Neumann, A. W. (1972). Surface topography: its influence on wetting and adhesion in a dental adhesive system. J. Dent. Res. 51, 780-788. doi:10.1177/00220345720510031401

El Feninat, F., Ellis, T. H., Sacher, E., and Stangel, I. (2001). A tapping mode AFM study of collapse and denaturation in dentinal collagen. Dent. Mater. 17, 284-288. doi:10.1016/s0109-5641(00)00083-x

Elliott, R. P., Straka, R. P., and Garibaldi, J. A. (1964). Polyphosphate inhibition of growth of pseudomonads from poultry meat. Appl. Microbiol. 12, 517-522. doi:10.1128/aem.12.6.517-522.1964

Englander, H. R., and Keyes, P. H. (1970). Effect of phosphate supplements on cavitation in hamsters infected with caries-conductive streptococci. J. Dent. Res. 49, 140-144. doi:10.1177/00220345700490010801

Eymirli, A., Nagas, E., Uyanik, M. O., and Cehreli, Z. C. (2017). Effect of laseractivated irrigation with ethylene diaminetetraacetic acid and phytic acid on the removal of calcium hydroxide and triple antibiotic paste from root dentin. Photomed. Laser Surg. 35, 43-48. doi:10.1089/pho.2016.4146

FAO/IZiNCG (2018). FAO/INFOODS/IZiNCG global food composition database for phytate. Version 1.0 Phyfoodcomp 1.0. FAO/IZiNCG: Rome, Italy.

Fernández, D., Ortega-Castro, J., and Frau, J. (2017). Theoretical study of the HAP crystal growth inhibition potency of pyrophosphate, etidronate, citrate and phytate. Deciphered the adsorbed conformation of phytate on the HAP (001) surface. Appl. Surf. Sci. 408, 110-116. doi:10.1016/j.apsusc.2017.03.008

Foreman, P. C., and Barnes, I. E. (1990). Review of calcium hydroxide. Int. Endod. J. 23, 283-297. doi:10.1111/j.1365-2591.1990.tb00108.x

Forgione, D., Nassar, M., Seseogullari-Dirihan, R., Thitthaweerat, S., and TezvergilMutluay, A. (2021). The effect of phytic acid on enzymatic degradation of dentin. Eur. J. Oral. Sci. e12771. doi:10.1111/eos.12771

Fox, C. H., and Eberl, M. (2002). Phytic acid (IP6), novel broad spectrum antineoplastic agent: a systematic review. Complement. Ther. Med. 10, 229-234. doi:10.1016/s0965-2299(02)00092-4

Frankenberger, R., Lohbauer, U., Roggendorf, M. J., Naumann, M., and Taschner, M. (2008). Selective enamel etching reconsidered: better than etch-and-rinse and self-etch? J. Adhes. Dent. 10, 339-344.
França, F. L., França-Botelho, A. D. C., and Araújo, F. G. S. (2018). Phosphoric acid increases the porosity and extends the contact area of dental osseo integrated implants. Int. J. Adv. Eng. Res. Sci. 5, 230-236. doi:10.22161/ijaers.5.3.30

Funao, H., Nagai, S., Sasaki, A., Hoshikawa, T., Tsuji, T., Okada, Y., et al. (2016). A novel hydroxyapatite film coated with ionic silver via inositol hexaphosphate chelation prevents implant-associated infection. Sci. Rep. 6, 23238. doi:10.1038/ srep23238

Fusayama, T., Nakamura, M., Kurosaki, N., and Iwaku, M. (1979). Non-pressure adhesion of a new adhesive restorative resin. J. Dent. Res. 58, 1364-1370. doi:10. 1177/00220345790580041101

Galler, K. M., Buchalla, W., Hiller, K. A., Federlin, M., Eidt, A., Schiefersteiner, M., et al. (2015). Influence of root canal disinfectants on growth factor release from dentin. J. Endod. 41, 363-368. doi:10.1016/ j.joen.2014.11.021

Galler, K. M., Widbiller, M., Buchalla, W., Eidt, A., Hiller, K. A., Hoffer, P. C., et al. (2016). EDTA conditioning of dentine promotes adhesion, migration and differentiation of dental pulp stem cells. Int. Endod. J. 49, 581-590. doi:10. 1111/iej.12492

García-Godoy, F., Loushine, R. J., Itthagarun, A., Weller, R. N., Murray, P. E., Feilzer, A. J., et al. (2005). Application of biologically-oriented dentin bonding principles to the use of endodontic irrigants. Am. J. Dent. 18, 281-290.

Garlich, J. R., Masterson, T. T., and Frank, R. K. (1994). Phytate antimicrobial compounds in oral care products. US5300289A.

Gbureck, U., Barralet, J. E., Spatz, K., Grover, L. M., and Thull, R. (2004). Ionic modification of calcium phosphate cement viscosity. Part I: hypodermic injection and strength improvement of apatite cement. Biomaterials 25, 2187-2195. doi:10.1016/j.biomaterials.2003.08.066

Govindasamy, V., Abdullah, A. N., Ronald, V. S., Musa, S., Ab. Aziz, Z. A., Zain, R. B., et al. (2010). Inherent differential propensity of dental pulp stem cells derived from human deciduous and permanent teeth. J. Endodontics 36, 1504-1515. doi:10.1016/j.joen.2010.05.006

Graf, E., and Eaton, J. W. (1990). Antioxidant functions of phytic acid. Free Radic. Biol. Med. 8, 61-69. doi:10.1016/0891-5849(90)90146-a

Graf, E., Empson, K. L., and Eaton, J. W. (1987). Phytic acid. A natural antioxidant. J. Biol. Chem. 262, 11647-11650. doi:10.1016/s0021-9258(18)60858-0

Graf, E. (1983). Applications of phytic acid. J. Am. Oil Chem. Soc. 60, 1861-1867. doi:10.1007/bf02901539

Graham, L., Cooper, P. R., Cassidy, N., Nor, J. E., Sloan, A. J., and Smith, A. J. (2006). The effect of calcium hydroxide on solubilisation of bio-active dentine matrix components. Biomaterials 27, 2865-2873. doi:10.1016/j.biomaterials. 2005.12.020

Grases, F., and Costa-Bauzá, A. (1999). Phytate (IP6) is a powerful agent for preventing calcifications in biological fluids: usefulness in renal lithiasis treatment. Anticancer Res. 19, 3717-3722.

Grases, F., Costa-Bauza, A., and Prieto, R. M. (2006). Renal lithiasis and nutrition. Nutr. J. 5, 23. doi:10.1186/1475-2891-5-23

Grases, F., Perelló, J., Sanchis, P., Isern, B., Prieto, R. M., Costa-Bauzá, A., et al. (2009). Anticalculus effect of a triclosan mouthwash containing phytate: a double-blind, randomized, three-period crossover trial. J. Periodont Res. 44, 616-621. doi:10.1111/j.1600-0765.2008.01168.x

Grases, F., Ramis, M., and Costa-Bauzá, A. (2000). Effects of phytate and pyrophosphate on brushite and hydroxyapatite crystallization. Comparison with the action of other polyphosphates. Urol. Res. 28, 136-140. doi:10.1007/ s002400050152

Grases, F., Söhnel, O., Zelenková, M., and Rodriguez, A. (2015). Phytate effects on biological hydroxyapatite development. Urolithiasis 43, 571-572. doi:10.1007/ s00240-015-0814-0

Greiner, R., Konietzny, U., and Jany, K. (2006). Phytate-an undesirable constituent of plant-based foods? J. für Ernährungsmedizin 8, 18-28.

Grenby, T. H. (1967a). Flour, bread and wheat grain fractions in decalcification tests. Arch. Oral Biol. 12, 513-521. doi:10.1016/0003-9969(67)90025-8

Grenby, T. H. (1967b). Phytates in decalcification tests in vitro. Arch. Oral Biol. 12, 531-537. doi:10.1016/0003-9969(67)90027-1

Grenby, T. H. (1973). Trials of 3 organic phosphorus-containing compounds as protective agents against dental caries in rats. J. Dent. Res. 52, 454-461. doi:10. $1177 / 00220345730520031201$ 
Grenby, T. H. (1967c). Wheat bran factors in decalcification tests. Arch. Oral Biol. 12, 523-529. doi:10.1016/0003-9969(67)90026-x

Grenby, T. H. (1966). White and wholemeal bread and flour in the diet of cariessusceptible rats. Br. Dent. J. 121, 26-29.

Grynspan, F., and Cheryan, M. (1983). Calcium phytate: effect of pH and molar ratio on in vitro solubility. J. Am. Oil Chem. Soc. 60, 1761-1764. doi:10.1007/ bf02680350

Gupta, R. K., Gangoliya, S. S., and Singh, N. K. (2015). Reduction of phytic acid and enhancement of bioavailable micronutrients in food grains. J. Food Sci. Technol. 52, 676-684. doi:10.1007/s13197-013-0978-y

Haapasalo, M., Shen, Y., Wang, Z., and Gao, Y. (2014). Irrigation in endodontics. Br. Dent J. 216, 299-303. doi:10.1038/sj.bdj.2014.204

Halvorsrud, K., Lewney, J., Craig, D., and Moynihan, P. J. (2019). Effects of starch on oral health: systematic review to inform WHO guideline. J. Dent. Res. 98, 46-53. doi:10.1177/0022034518788283

Hanakahi, L. A., Bartlet-Jones, M., Chappell, C., Pappin, D., and West, S. C. (2000). Binding of inositol phosphate to DNA-PK and stimulation of double-strand break repair. Cell 102, 721-729. doi:10.1016/s0092-8674(00)00061-1

Handelman, S. L., and Kreinces, G. H. (1973). Effect of phosphate and pH on Streptococcus mutans acid production and growth. J. Dent. Res. 52, 651-657. doi:10.1177/00220345730520040301

He, W., Yin, X., Xie, L., Liu, Z., Li, J., Zou, S., et al. (2019). Enhancing osseointegration of titanium implants through large-grit sandblasting combined with micro-arc oxidation surface modification. J. Mater. Sci. Mater. Med. 30, 73. doi:10.1007/s10856-019-6276-0

Hennequin, M., Pajot, J., and Avignant, D. (1994). Effects of different $\mathrm{pH}$ values of citric acid solutions on the calcium and phosphorus contents of human root dentin. J. Endod. 20, 551-554. doi:10.1016/S0099-2399(06)80071-3

Hentenaar, D. F. M., De Waal, Y. C. M., Strooker, H., Meijer, H. J. A., Van Winkelhoff, A. J., et al. (2017). Implant decontamination with phosphoric acid during surgical peri-implantitis treatment: a RCT. Int. J. Implant Dent. 3, 33. doi:10.1186/s40729-017-0091-5

Hill, E. E. (2007). Dental cements for definitive luting: a review and practical clinical considerations. Dent. Clin. North Am. 51, 643-658vi. doi:10.1016/j. cden.2007.04.002

Hoke, I. S. H., Strand, R., Wang, X., and Zhang, Y. (2016). Oral care compositions comprising phytic acid. Google Patents WO2013007018A1.

Horiguchi, Y., Yoshikawa, A., Oribe, K., and Aizawa, M. (2008). Fabrication of chelate-setting hydroxyapatite cements from four kinds of commerciallyavailable powder with various shape and crystallinity and their mechanical property. J. Ceram. Soc. Jpn. 116, 50-55. doi:10.2109/jcersj2.116.50

Hsieh, S. C., Teng, N. C., Lin, Y. C., Lee, P. Y., Ji, D. Y., Chen, C. C., et al. (2009). A novel accelerator for improving the handling properties of dental filling materials. J. Endod. 35, 1292-1295. doi:10.1016/j.joen.2009.06.007

$\mathrm{Hu}, \mathrm{X}$., Ling, J., and Gao, Y. (2010). Effects of irrigation solutions on dentin wettability and roughness. J. Endod. 36, 1064-1067. doi:10.1016/j.joen.2010.03.007

Hunt, J. R. (2002). Moving toward a plant-based diet: are iron and zinc at risk? Nutr. Rev. 60, 127-134. doi:10.1301/00296640260093788

Hurle, K., Weichhold, J., Brueckner, M., Gbureck, U., Brueckner, T., and GoetzNeunhoeffer, F. (2018). Hydration mechanism of a calcium phosphate cement modified with phytic acid. Acta Biomater. 80, 378-389. doi:10.1016/j.actbio. 2018.09.002

Hurrell, R. F. (2003). Influence of vegetable protein sources on trace element and mineral bioavailability. J. Nutr. 133, 2973S-7S. doi:10.1093/jn/133.9.2973S

Imbery, T. A., Kennedy, M., Janus, C., and Moon, P. C. (2012). Evaluating EDTA as a substitute for phosphoric acid-etching of enamel and dentin. Gen. Dent. 60, e55-61.

Inagawa, J., Kiyosawa, I., and Nagasawa, T. (1987). Effects of phytic acid on the digestion of casein and soybean protein with trypsin, pancreatin or pepsin. Jjsnfs 40, 367-373. doi:10.4327/jsnfs.40.367

Jagzap, J. B., Patil, S. S., Gade, V. J., Chandhok, D. J., Upagade, M. A., and Thakur, D. A. (2017). Effectiveness of three different irrigants-17\% ethylenediaminetetraacetic acid, Q-MIX, and phytic acid in smear layer removal: a comparative scanning electron microscope study. Contemp. Clin. Dent. 8, 459-463. doi:10.4103/ccd. ccd_524_17

Jenkins, G. N., Forster, M. G., and Speirs, R. L. (1959a). The influence of the refinement of carbohydrates on their cariogenicity. In vitro studies on crude and refined sugars and animal experiments. Br. Dent. J. 106, 362-374.
Jenkins, G. N., Forster, M. G., Spetrs, R. L., and Kleinberg, I. (1959b). The Influence of the refinement of carbohydrates on their cariogenicity. In vitro experiments on white and brown flour. Br. dent. J. 106, 195-208.

Jenkins, G. N. (1966). The refinement of foods in relation to dental caries. Adv. Oral Biol. 2, 67-100. doi:10.1016/b978-1-4832-3118-1.50011-6

Johnson, L. F., and Tate, M. E. (1969). Structure of "phytic acids". Can. J. Chem. 47, 63-73. doi:10.1139/v69-008

Johnsson, M., Richardson, C. F., Bergey, E. J., Levine, M. J., and Nancollas, G. H. (1991). The effects of human salivary cystatins and statherin on hydroxyapatite crystallization. Arch. Oral Biol. 36, 631-636. doi:10.1016/ 0003-9969(91)90014-1

Kancheva, V. D., and Kasaikina, O. T. (2013). Bio-antioxidants-a chemical base of their antioxidant activity and beneficial effect on human health. Curr. Med. Chem. 20, 4784-4805. doi:10.2174/09298673113209990161

Kaufman, H. W. (1986). Interactions of inositol phosphates with mineralized tissues. in Phytic acid: chemistry and applications. Editor E. Graf. Minneapolis, USA: Pilatus Press, 303-320.

Kaufman, H. W., and Kleinberg, I. (1970). The effect of $\mathrm{pH}$ on the adsorption properties of the phytate molecule. Arch. Oral Biol. 15, 917-934. doi:10.1016/ 0003-9969(70)90088-9

Kim, J. S., Jang, S. W., Son, M., Kim, B. M., and Kang, M. J. (2016). Enteric-coated tablet of risedronate sodium in combination with phytic acid, a natural chelating agent, for improved oral bioavailability. Eur. J. Pharm. Sci. 82, 45-51. doi:10.1016/j.ejps.2015.11.011

Kim, N. H., and Rhee, M. S. (2016). Phytic acid and sodium chloride show marked synergistic bactericidal effects against nonadapted and acid-adapted Escherichia coli O157:H7 strains. Appl. Environ. Microbiol. 82, 1040-1049. doi:10.1128/ AEM.03307-15

Kim, S. G., Malek, M., Sigurdsson, A., Lin, L. M., and Kahler, B. (2018). Regenerative endodontics: a comprehensive review. Int. Endod. J. 51, 1367-1388. doi:10.1111/iej.12954

Kleinberg, I., Acevedo, A. M., and Chatterjee, R. (1998). Anti-caries oral compositions. Google Patents WO1997032565A1.

Knuckles, B. E., and Betschart, A. A. (1987). Effect of phytate and other myo-inositol phosphate esters on $\alpha$-amylase digestion of starch. J. Food Sci. 52, 719-721. doi:10. 1111/j.1365-2621.1987.tb06710.x

Knuckles, B. E. (1988). Effect of phytate and other myo-inositol phosphate esters on lipase activity. J. Food Sci. 53, 250-252. doi:10.1111/j.1365-2621.1988. tb10221.x

Kong, K., Hiraishi, N., Nassar, M., Otsuki, M., Yiu, C. K. Y., and Tagami, J. (2017). Effect of phytic acid etchant on resin-dentin bonding: monomer penetration and stability of dentin collagen. J. Prosthodont. Res. 61, 251-258. doi:10.1016/j. jpor.2016.10.001

Kong, K., Islam, M. S., Nassar, M., Hiraishi, N., Otsuki, M., Yiu, C. K. Y., et al. (2015). Effect of phytic acid etchant on the structural stability of demineralized dentine and dentine bonding. J. Mech. Behav. Biomed. Mater. 48, 145-152. doi:10.1016/j.jmbbm.2015.03.027

König, K. G., and Grenby, T. H. (1965). The effect of wheat grain fractions and sucrose mixtures on rat caries developing in two strains of rats maintained on different regimes and evaluated by two different methods. Arch. Oral Biol. 10, 143-153. doi:10.1016/0003-9969(65)90066-x

Konishi, T., Mizumoto, M., Honda, M., Zhuang, Z., and Aizawa, M. (2012). Fabrication of chelate-setting cements from hydroxyapatite powders surfacemodified with various sodium inositol hexaphosphate concentrations and their mechanical properties. Proced. Eng. 36, 137-143. doi:10.1016/j.proeng.2012.03.021

Koutsoukos, P. G., Amjad, Z., and Nancollas, G. H. (1981). The influence of phytate and phosphonate on the crystal growth of fluorapatite and hydroxyapatite. J. Colloid Interf. Sci. 83, 599-605. doi:10.1016/0021-9797(81)90354-4

Lee, H., Jeong, C., Ghafoor, K., Cho, S., and Park, J. (2011). Oral delivery of insulin using chitosan capsules cross-linked with phytic acid. Biomed. Mater. Eng. 21, 25-36. doi:10.3233/BME-2011-0654

Li, A., and Qiu, D. (2011). Phytic acid derived bioactive $\mathrm{CaO}-\mathrm{P} 2 \mathrm{O} 5-\mathrm{SiO}_{2}$ gelglasses. J. Mater. Sci. Mater. Med. 22, 2685-2691. doi:10.1007/s10856-0114464-7

Li, J., Forberg, S., and Söremark, R. (1994). Influence of phytic acid on zinc phosphate cement. Acta Odontol. Scand. 52, 209-213. doi:10.3109/ 00016359409029048 
Lilienthal, B., Bush, E., Buckmaster, M., Gregory, G., Gagolski, J., Smythe, B. M., et al. (1966). The cariostatic effect of carbohydrate phosphates in the diet. Aust. Dent. J. 11, 388-395. doi:10.1111/j.1834-7819.1966.tb03799.x

Limbasuta, S., Singh, B., and Johansen, E. (1961). The effect of sodium phytate and sodium acid pyrophosphate on rat caries. J. Dent. Res. 40, 658.

Lingström, P., van Houte, J., and Kashket, S. (2000). Food starches and dental caries. Crit. Rev. Oral Biol. Med. 11, 366-380. doi:10.1177/ 10454411000110030601

Lippert, F. (2013). An introduction to toothpaste - its purpose, history and ingredients. Monogr. Oral Sci. 23, 1. doi:10.1159/000350456

Liu, K., Zhang, H., Lu, M., Liu, L., Yan, Y., Chu, Z., et al. (2019). Enhanced bioactive and osteogenic activities of titanium by modification with phytic acid and calcium hydroxide. Appl. Surf. Sci. 478, 162-175. doi:10.1016/j.apsusc.2019. 01.219

López-González, A. A., Grases, F., Roca, P., Mari, B., Vicente-Herrero, M. T., and Costa-Bauzá, A. (2008). Phytate (myo-inositol hexaphosphate) and risk factors for osteoporosis. J. Med. Food 11, 747-752. doi:10.1089/jmf.2008.0087

Macedo, G. V., Yamauchi, M., and Bedran-Russo, A. K. (2009). Effects of chemical cross-linkers on caries-affected dentin bonding. J. Dent. Res. 88, 1096-1100. doi:10.1177/0022034509351001

Machado-Silveiro, L. F., González-López, S., and González-Rodríguez, M. P. (2004). Decalcification of root canal dentine by citric acid, EDTA and sodium citrate. Int. Endod. J. 37, 365-369. doi:10.1111/j.1365-2591.2004. 00813.x

Madsen, K. O., and Edmonds, E. J. (1962). Effect of rice hulls and other seed hulls on dental caries production in the cotton rat. J. Dent. Res. 41, 405-412. doi:10. 1177/00220345620410021201

Magrill, D. S. (1973a). Phytate inhibition of enamel hardening by mineralizing solutions. J. Dent. Res. 52, 1342. doi:10.1177/00220345730520063401

Magrill, D. S. (1973b). The reduction of the solubility of hydroxyapatite in acid by adsorption of phytate from solution. Arch. Oral Biol. 18, 591-600. doi:10.1016/ 0003-9969(73)90097-6

Martin, J. Y., Schwartz, Z., Hummert, T. W., Schraub, D. M., Simpson, J., Lankford, J., Jr., et al. (1995). Effect of titanium surface roughness on proliferation, differentiation, and protein synthesis of human osteoblast-like cells (MG63). J. Biomed. Mater. Res. 29, 389-401. doi:10.1002/jbm.820290314

Mazzoni, A., Tjäderhane, L., Checchi, V., Di Lenarda, R., Salo, T., Tay, F. R., et al. (2015). Role of dentin MMPs in caries progression and bond stability. J. Dent. Res. 94, 241-251. doi:10.1177/0022034514562833

McArthur, C., Sanson, G. D., and Beal, A. M. (1995). Salivary proline-rich proteins in mammals: roles in oral homeostasis and counteracting dietary tannin. J. Chem. Ecol. 21, 663-691. doi:10.1007/BF02033455

McClure, F. J. (1964). Cariostatic effect of phosphates. Science 144, 1337-1338. doi:10.1126/science.144.3624.1337

McClure, F. J. (1960). The cariostatic effect in white rats of phosphorus and calcium supplements added to the flour of bread formulas and to bread diets. J. Nutr. 72, 131-136. doi:10.1093/jn/72.2.131

McClure, F. J. (1963). Further studies on the cariostatic effect of organic and inorganic phosphates. J. Dent. Res. 42, 693-699. doi:10.1177/ 00220345630420021801

Medvecky, L., Stulajterova, R., Giretova, M., Sopcak, T., Molcanova, Z., and Koval, K. (2020). Enzymatically hardened calcium phosphate biocement with phytic acid addition. J. Mater. Sci. Mater. Med. 31, 54. doi:10.1007/s10856-020-06387-5

Meininger, S., Blum, C., Schamel, M., Barralet, J. E., Ignatius, A., and Gbureck, U. (2017). Phytic acid as alternative setting retarder enhanced biological performance of dicalcium phosphate cement in vitro. Sci. Rep. 7, 558-610. doi:10.1038/s41598-017-00731-6

Meyer, F., Amaechi, B. T., Fabritius, H. O., and Enax, J. (2018). Overview of calcium phosphates used in biomimetic oral care. Open Dent. J. 12, 406. doi:10. 2174/1874210601812010406

Milleman, K. R., Creeth, J. E., Burnett, G. R., and Milleman, J. L. (2018). A randomized clinical trial to evaluate the stain removal efficacy of a sodium phytate dentifrice formulation. J. Esthet. Restor. Dent. 30, E45-E51. doi:10. 1111 /jerd. 12355

Millett, D. T., Glenny, A. M., Mattick, R. C., Hickman, J., and Mandall, N. A. (2016). Adhesives for fixed orthodontic bands. Cochrane Database Syst. Rev. 10, CD004485. doi:10.1002/14651858.CD004485
Miyamoto, S., Kuwata, G., Imai, M., Nagao, A., and Terao, J. (2000). Protective effect of phytic acid hydrolysis products on iron-induced lipid peroxidation of liposomal membranes. Lipids 35, 1411. doi:10. 1007/s11745-000-0659-y

Mocquot, C., Attik, N., Pradelle-Plasse, N., Grosgogeat, B., and Colon, P. (2020). Bioactivity assessment of bioactive glasses for dental applications: a critical review. Dent. Mater. 36, 1116-1143. doi:10.1016/j.dental.2020.03.020

Morris, C., Fichtel, S. L., and Taylor, A. J. (2011). Impact of calcium on salivary a-amylase activity, starch paste apparent viscosity, and thickness perception. Chem. Percept. 4, 116. doi:10.1007/s12078-011-9091-7

Muana, H. L., Nassar, M., Dargham, A., Hiraishi, N., and Tagami, J. (2020). Effect of smear layer removal agents on the microhardness and roughness of radicular dentin. Saudi Dent. J. doi:10.1016/j.sdentj.2020.05.001

Murray, P. E., Garcia-Godoy, F., and Hargreaves, K. M. (2007). Regenerative endodontics: a review of current status and a call for action. J. Endod. 33, 377-390. doi:10.1016/j.joen.2006.09.013

Nakajima, M., Okuda, M., Pereira, P., Tagami, J., and Pashley, D. H. (2002). Dimensional changes and ultimate tensile strengths of wet decalcified dentin applied with one-bottle adhesives. Dent. Mater. 18, 603-608. doi:10.1016/ s0109-5641(02)00004-0

Nakauchi, G., Eshita, Y., and Takahashi, K. (2017). Tooth whitener. US9757315B2.

Napper, D. H., and Smythe, B. M. (1966). The dissolution kinetics of hydroxyapatite in the presence of kink poisons. J. Dent. Res. 45, 1775-1783. doi:10.1177/00220345660450063201

Nassar, M., Hiraishi, N., Shimokawa, H., Tamura, Y., Otsuki, M., Kasugai, S., et al. (2014). The inhibition effect of non-protein thiols on dentinal matrix metalloproteinase activity and HEMA cytotoxicity. J. Dent. 42, 312-318. doi:10.1016/j.jdent.2013.11.023

Nassar, M., Hiraishi, N., Tamura, Y., Otsuki, M., Aoki, K., and Tagami, J. (2015). Phytic acid: an alternative root canal chelating agent. J. Endod. 41, 242-247. doi:10.1016/j.joen.2014.09.029

Nassar, M., Hiraishi, N., Islam, M. S., Aizawa, M., Tamura, Y., Otsuki, M., et al. (2013). Effect of phytic acid used as etchant on bond strength, smear layer, and pulpal cellsEffect of phytic acid used as etchant on bond strength, smear layer, and pulpal cells. Eur. J. Oral Sci. 121, 482-487. doi:10.1111/eos. 12064

Nassar, M., Hiraishi, N., Islam, M. S., Romero, M. J. R. H., Otsuki, M., and Tagami, J. (2020). Effect of phytic acid as an endodontic chelator on resin adhesion to sodium hypochlorite-treated dentin. Restor. Dent. Endod. 45, e44. doi:10.5395/ rde.2020.45.e44

Nassar, R. I., and Nassar, M. (2017). Antimicrobial effect of phytic acid on Enterococcus faecalis. Int. Arab. J. Antimicrob. Agents 6, 1-7. doi:10.1515/ 9781503603189

Nezu, T., and Winnik, F. M. (2000). Interaction of water-soluble collagen with poly (acrylic acid). Biomaterials 21, 415-419. doi:10.1016/s0142-9612(99)00204-5

Nikhil, V., Jaiswal, S., Bansal, P., Arora, R., Raj, S., and Malhotra, P. (2016). Effect of phytic acid, ethylenediaminetetraacetic acid, and chitosan solutions on microhardness of the human radicular dentin. J. Conserv. Dent. 19, 179-183. doi:10.4103/0972-0707.178705

Nissar, J., Ahad, T., Naik, H. R., and Hussain, S. Z. (2017). A review phytic acid: as antinutrient or nutraceutical. J. Pharmacogn. Phytochem. 6, 1554-1560.

Nordbö, H., and Rölla, G. (1972). Desorption of salivary proteins from hydroxyapatite by phytic acid and glycerophosphate and the plaqueinhibiting effect of the two compounds in vivo. J. Dent. Res. 51, 800-802. doi:10.1177/00220345720510031701

Norris, F. A., Ungewickell, E., and Majerus, P. W. (1995). Inositol hexakisphosphate binds to clathrin assembly protein 3 (AP-3/AP180) and inhibits clathrin cage assembly in vitro. J. Biol. Chem. 270, 214-217. doi:10. 1074/jbc.270.1.214

Oatway, L., Vasanthan, T., and Helm, J. H. (2001). Phytic acid. Food Rev. Int. 17, 419-431. doi:10.1081/fri-100108531

Nygaard-Ostby, N. (1957). Chelating in root canal therapy. Ethylene-diamine tetraacetic acid for cleansing and widening of root canals. Odontol. Tidskr. $65,3-11$.

Pajor, K., Pajchel, L., and Kolmas, J. (2019). Hydroxyapatite and fluorapatite in conservative dentistry and oral implantology-a review. Materials 12, 2683. doi:10.3390/ma12172683 
Pallauf, J., and Rimbach, G. (1997). Nutritional significance of phytic acid and phytase. Arch. Tierernahr 50, 301-319. doi:10.1080/17450399709386141

Palmquist, A., Omar, O. M., Esposito, M., Lausmaa, J., and Thomsen, P. (2010). Titanium oral implants: surface characteristics, interface biology and clinical outcome. J. R. Soc. Interf. 7 Suppl 5, S515-S527. doi:10.1098/rsif.2010.0118.focus

Parkinson, C. R., Burnett, G. R., Creeth, J. E., Lynch, R. J. M., Budhawant, C., Lippert, F., et al. (2018). Effect of phytate and zinc ions on fluoride toothpaste efficacy using an in situ caries model. J. Dent. 73, 24-31. doi:10.1016/j.jdent. 2018.03.013

Pashley, D. H., Ciucchi, B., Sano, H., and Horner, J. A. (1993). Permeability of dentin to adhesive agents. Quintessence Int. 24, 618-631.

Pashley, D. H., Tay, F. R., Yiu, C., Hashimoto, M., Breschi, L., Carvalho, R., et al. (2004). Collagen degradation by host-derived enzymes during aging. J. Dent. Res. 83, 216-221. doi:10.1177/154405910408300306

Pashley, D. H. (1992). The effects of acid etching on the pulpodentin complex. Oper. Dent. 17, 229-242.

Persson, H., Türk, M., Nyman, M., and Sandberg, A. S. (1998). Binding of $\mathrm{Cu}^{2+}$, $\mathrm{Zn}^{2+}$, and $\mathrm{Cd}^{2+}$ to inositol tri-, tetra-, penta-, and hexaphosphates. J. Agric. Food Chem. 46, 3194-3200. doi:10.1021/jf971055w

Pető, G., Karacs, A., Pászti, Z., Guczi, L., Divinyi, T., and Joób, A. (2002). Surface treatment of screw shaped titanium dental implants by high intensity laser pulses. Appl. Surf. Sci. 186, 7-13.

Pfeffer, E. (1872). The inositol phosphates: chemical synthesis and biological significance. Jahrb Wiss Bot. 8, 429.

Porciani, P. F., Grandini, S., and Sapio, S. (2003). Anticalculus efficacy of a chewing gum with polyphosphates in a twelve-week single-blind trial. J. Clin. Dent. 14, 45-47.

Post, F. J., Krishnamurty, G. B., and Flanagan, M. D. (1963). Influence of sodium hexametaphosphate on selected bacteria. Appl. Microbiol. 11, 430-435. doi:10. 1128/aem.11.5.430-435.1963

Posternak, S. (1903). Sur un nouveau principe phospho-organique d'origine végétale, la phytine. Compt. Rend. Soc. de Biol. 55, 1190-1192.

Prado, M., Gusman, H., Gomes, B. P., and Simão, R. A. (2011). Scanning electron microscopic investigation of the effectiveness of phosphoric acid in smear layer removal when compared with EDTA and citric acid. J. Endod. 37, 255-258. doi:10.1016/j.joen.2010.11.011

Prati, C., Chersoni, S., and Pashley, D. H. (1999). Effect of removal of surface collagen fibrils on resin-dentin bonding. Dent. Mater. 15, 323-331. doi:10.1016/ s0109-5641(99)00052-4

Prosser, H. J., Brant, P. J., Scott, R. P., and Wilson, A. D. (1983). The cementforming properties of phytic acid. J. Dent. Res. 62, 598-600. doi:10.1177/ 00220345830620052001

Pruitt, K. M., Jamieson, A. D., and Caldwell, R. C. (1970). Possible basis for the cariostatic effect of inorganic phosphates. Nature 225, 1249. doi:10.1038/ $2251249 \mathrm{a} 0$

Ravichandran, R., Seitz, V., Reddy Venugopal, J., Sridhar, R., Sundarrajan, S., Mukherjee, S., et al. (2013). Mimicking native extracellular matrix with phytic acid-crosslinked protein nanofibers for cardiac tissue engineering. Macromol. Biosci. 13, 366-375. doi:10.1002/mabi.201200391

Ravindran, V., Bryden, W. L., and Kornegay, E. T. (1995). Phytates: occurrence, bioavailability and implications in poultry nutrition. Poult. Avian Biol. Rev. 6, 125-143.

Reddy, N. R., Pierson, M. D., Sathe, S. K., and Salunkhe, D. K. (1989). Phytates in cereals and legumes. Boca Raton, FL: CRC Press.

Reddy, N. R., and Salunkhe, D. K. (1981). Interactions between phytate, protein, and minerals in whey fractions of black gram. J. Food Sci. 46, 564-567. doi:10. 1111/j.1365-2621.1981.tb04911.x

Reddy, N. R. , Sathe, S. K., and Salunkhe, D. K. (1982). Phytates in legumes and cereals. Adv. Food Res. 28, 1-92. doi:10.1016/s0065-2628(08)60110-x

Ren, H., Tian, Y., Li, A., Martin, R. A., and Qiu, D. (2017). The influence of phosphorus precursor on the structure and properties of SiO2-P2O5-CaO bioactive glass. Biomed. Phys. Eng. Express. 3, 045017. http://dx.doi.org/10. 1088/2057-1976/aa7daa.

Rickard, S. E., and Thompson, L. U. (1997). "Interactions and biological effects of phytic acid," in Antinutrients and phytochemicals in food. Editor F. Shahidi (Washington, DC: American Chemical Society), 294-312.

Rodrigues, L., Espanca, R., Costa, A. R., Antunes, C. M., Pomar, C., Capela-Silva, F., et al. (2019). Comparison of salivary proteome of children with different sensitivities for bitter and sweet tastes: association with body mass index. Int. J. Obes. 43, 701-712. doi:10.1038/s41366-018-0289-5
Rose, H. E., and Quarterman, J. (1984). Effects of dietary phytic acid on lead and cadmium uptake and depletion in rats. Environ. Res. 35, 482-489. doi:10.1016/ 0013-9351(84)90154-3

Sands, S. H., Biskobing, S. J., and Olson, R. M. (1986). Commerical aspects of phytic acid: an overview. Phytic acid: chemistry and applications. Minneapolis, MN: Pilatus Press.

Sano, H., Shono, T., Takatsu, T., and Hosoda, H. (1994). Microporous dentin zone beneath resin-impregnated layer. Oper. Dent. 19, 59-64.

Sasakawa, N., Sharif, M., and Hanley, M. R. (1995). Metabolism and biological activities of inositol pentakisphosphate and inositol hexakisphosphate. Biochem. Pharmacol. 50, 137-146. doi:10.1016/0006-2952(95)00059-9

Scannapieco, F. A., Solomon, L., and Wadenya, R. O. (1994). Emergence in human dental plaque and host distribution of amylase-binding streptococci. J. Dent. Res. 73, 1627-1635. doi:10.1177/00220345940730100701

Scannapieco, F. A., Torres, G., and Levine, M. J. (1993). Salivary alpha-amylase: role in dental plaque and caries formation. Crit. Rev. Oral Biol. Med. 4, 301-307. doi:10.1177/10454411930040030701

Schlemmer, U., Frølich, W., Prieto, R. M., and Grases, F. (2009). Phytate in foods and significance for humans: food sources, intake, processing, bioavailability, protective role and analysis. Mol. Nutr. Food Res. 53 Suppl 2, S330-S375. doi:10. 1002/mnfr.200900099

Selle, P. H., Cowieson, A. J., Cowieson, N. P., and Ravindran, V. (2012). Proteinphytate interactions in pig and poultry nutrition: a reappraisal. Nutr. Res. Rev. 25, 1-17. doi:10.1017/S0954422411000151

Shafie, N. H., Esa, N. M., Ithnin, H., Saad, N., and Pandurangan, A. K. (2013). Proapoptotic effect of rice bran inositol hexaphosphate (IP6) on HT-29 colorectal cancer cells. Int. J. Mol. Sci. 14, 23545-23558. doi:10.3390/ijms141223545

Sharma, C. B., Goel, M., and Irshad, M. (1978). Myoinositol hexaphosphate as a potential inhibitor of $\alpha$-amylases. Phytochemistry 17, 201-204. doi:10.1016/ s0031-9422(00)94146-3

Shears, S. B. (2001). Assessing the omnipotence of inositol hexakisphosphate. Cell. Signal. 13, 151-158. doi:10.1016/s0898-6568(01)00129-2

Sheikh, Z., Zhang, Y. L., Grover, L., Merle, G. E., Tamimi, F., and Barralet, J. (2015). In vitro degradation and in vivo resorption of dicalcium phosphate cement based grafts. Acta Biomater. 26, 338-346. doi:10.1016/j.actbio.2015.08.031

Shibata, H., and Morioka, T. (1982). Antibacterial action of condensed phosphates on the bacterium Streptococcus mutans and experimental caries in the hamster. Arch. Oral Biol. 27, 809-816. doi:10.1016/0003-9969(82)90034-6

Sidhu, S. K., and Nicholson, J. W. (2016). A review of glass-ionomer cements for clinical dentistry. J. Funct. Biomater. 7, 16. doi:10.3390/jfb7030016

Sillanpää, M. (1997). Environmental fate of EDTA and DTPA. Rev. Environ. Contam. Toxicol. 152, 85-111. doi:10.1007/978-1-4612-1964-4_3

Silva, E. O., and Bracarense, A. P. (2016). Phytic acid: from antinutritional to multiple protection factor of organic systems. J. Food Sci. 81, R1357-R1362. doi:10.1111/1750-3841.13320

Silva, P. V., Guedes, D. F., Nakadi, F. V., Pécora, J. D., and Cruz-Filho, A. M. (2013). Chitosan: a new solution for removal of smear layer after root canal instrumentation. Int. Endod. J. 46, 332-338. doi:10.1111/j.1365-2591.2012.02119.x

Singh, M., and Krikorian, A. D. (1982). Inhibition of trypsin activity in vitro by phytate. J. Agric. Food Chem. 30, 799-800. doi:10.1021/jf00112a049

Sloan, A. J., and Smith, A. J. (2007). Stem cells and the dental pulp: potential roles in dentine regeneration and repair. Oral Dis. 13, 151-157. doi:10.1111/j.16010825.2006.01346.x

Smith, A. J., Duncan, H. F., Diogenes, A., Simon, S., and Cooper, P. R. (2016). Exploiting the bioactive properties of the dentin-pulp complex in regenerative endodontics. J. Endod. 42, 47-56. doi:10.1016/j.joen.2015.10.019

Smith, A. J. (2003). Vitality of the dentin-pulp complex in health and disease: growth factors as key mediators. J. Dent Educ. 67, 678-689. doi:10.1002/j.00220337.2003.67.6.tb03668.x

Sonoyama, W., Liu, Y., Yamaza, T., Tuan, R. S., Wang, S., Shi, S., et al. (2008). Characterization of the apical papilla and its residing stem cells from human immature permanent teeth: a pilot study. J. Endod. 34, 166-171. doi:10.1016/j. joen.2007.11.021

Stuart, C. H., Schwartz, S. A., Beeson, T. J., and Owatz, C. B. (2006). Enterococcus faecalis: its role in root canal treatment failure and current concepts in retreatment. J. Endod. 32, 93-98. doi:10.1016/j.joen.2005.10.049

Szwergold, B. S., Graham, R. A., and Brown, T. R. (1987). Observation of inositol pentakis- and hexakis-phosphates in mammalian tissues by 31P NMR. 
Biochem. Biophys. Res. Commun. 149, 874-881. doi:10.1016/0006-291x(87) 90489-x

Tabak, L. A. (1990). Structure and function of human salivary mucins. Crit. Rev. Oral Biol. Med. 1, 229-234. doi:10.1177/10454411900010040201

Taketa, F., and Phillips, P. H. (1957). Oat hull fractions and the development of dental caries. J. Am. Diet. Assoc. 33, 575-578.

Tezvergil-Mutluay, A., Mutluay, M., Seseogullari-Dirihan, R., Agee, K. A., Key, W. O., Scheffel, D. L., et al. (2013). Effect of phosphoric acid on the degradation of human dentin matrix. J. Dent Res. 92, 87-91. doi:10.1177/0022034512466264

Thompson, J. M., Agee, K., Sidow, S. J., McNally, K., Lindsey, K., Borke, J., et al. (2012). Inhibition of endogenous dentin matrix metalloproteinases by ethylenediaminetetraacetic acid. J. Endod. 38, 62-65. doi:10.1016/j.joen.2011. 09.005

Thompson, L. U., and Yoon, J. H. (1984). Starch digestibility as affected by polyphenols and phytic acid. J. Food Sci. 49, 1228-1229. doi:10.1111/j.13652621.1984.tb10443.x

Toledano, M., Yamauti, M., Osorio, E., and Osorio, R. (2012). Zinc-inhibited MMP-mediated collagen degradation after different dentine demineralization procedures. Caries. Res. 46, 201-207. doi:10.1159/000337315

Tomson, P. L., Grover, L. M., Lumley, P. J., Sloan, A. J., Smith, A. J., and Cooper, P. R. (2007). Dissolution of bio-active dentine matrix components by mineral trioxide aggregate. J. Dent. 35, 636-642. doi:10.1016/j.jdent.2007.04.008

Torabinejad, M., Khademi, A. A., Babagoli, J., Cho, Y., Johnson, W. B., Bozhilov, K., et al. (2003). A new solution for the removal of the smear layer. J. Endod. 29, 170-175. doi:10.1097/00004770-200303000-00002

Torres, J., Domínguez, S., Cerdá, M. F., Obal, G., Mederos, A., Irvine, R. F., et al. (2005). Solution behaviour of myo-inositol hexakisphosphate in the presence of multivalent cations. Prediction of a neutral pentamagnesium species under cytosolic/nuclear conditions. J. Inorg. Biochem. 99, 828-840. doi:10.1016/j. jinorgbio.2004.12.011

Touger-Decker, R., and van Loveren, C. (2003). Sugars and dental caries. Am. J. Clin. Nutr. 78, 881S-892S. doi:10.1093/ajcn/78.4.881s

Trela, B. C. (2010). Iron stabilization with phytic acid in model wine and wine. Am. J. Enol Vitic. 61, 253-259.

Trevelin, L. T., Villanueva, J., Zamperini, C. A., Mathew, M. T., Matos, A. B., and Bedran-Russo, A. K. (2019). Investigation of five $\alpha$-hydroxy acids for enamel and dentin etching: demineralization depth, resin adhesion and dentin enzymatic activity. Dent. Mater. 35, 900-908. doi:10.1016/j.dental.2019.03.005

Tu, X., Chen, X., Peng, Y., Nan, J., Wei, B., He, L., et al. (2018). Modulation of the self-assembly of collagen by phytic acid: an in vitro study. Macromol. Res. 26, 1233-1240. doi:10.1007/s13233-019-7016-5

Ulusoy, Ö. İ., and Görgül, G. (2013). Effects of different irrigation solutions on root dentine microhardness, smear layer removal and erosion. Aust. Endod. J. 39, 66-72. doi:10.1111/j.1747-4477.2010.00291.x

Uyanik, O., Nagas, E., Kucukkaya Eren, S., Cehreli, Z. C., Vallittu, P. K., and Lassila, L. V. J. (2019). Effect of phytic acid on the setting times and tensile strengths of calcium silicate-based cements. Aust. Endod. J. 45, 241-245. doi:10.1111/aej. 12314

Van Meerbeek, B., Conn, L. J., Jr., Duke, E. S., Eick, J. D., Robinson, S. J., and Guerrero, D. (1996). Correlative transmission electron microscopy examination of nondemineralized and demineralized resin-dentin interfaces formed by two dentin adhesive systems. J. Dent. Res. 75, 879-888. doi:10.1177/ 00220345960750030401

Van Meerbeek, B., Inokoshi, S., Braem, M., Lambrechts, P., and Vanherle, G. (1992). Morphological aspects of the resin-dentin interdiffusion zone with different dentin adhesive systems. J. Dent. Res. 71, 1530-1540. doi:10.1177/ 00220345920710081301

Van Meerbeek, B., Yoshihara, K., Yoshida, Y., Mine, A., De Munck, J., and Van Landuyt, K. L. (2011). State of the art of self-etch adhesives. Dent. Mater. 27, 17-28. doi:10.1016/j.dental.2010.10.023

Violich, D. R., and Chandler, N. P. (2010). The smear layer in endodontics-a review. Int. Endod. J. 43, 2-15. doi:10.1111/j.1365-2591.2009.01627.x

Visse, R., and Nagase, H. (2003). Matrix metalloproteinases and tissue inhibitors of metalloproteinases: structure, function, and biochemistry. Circ. Res. 92, 827-839. doi:10.1161/01.RES.0000070112.80711.3D

Vitorino, R., de Morais Guedes, S., Ferreira, R., Lobo, M. J., Duarte, J., FerrerCorreia, A. J., et al. (2006). Two-dimensional electrophoresis study of in vitro pellicle formation and dental caries susceptibility. Eur. J. Oral Sci. 114, 147-153. doi:10.1111/j.1600-0722.2006.00328.x

Vogel, J. J., Thompson, D. J., and Phillips, P. H. (1962). Studies on the anticariogenic activity of oat hulls. J. Dent. Res. 41, 707-712. doi:10.1177/ 00220345620410032501

Vucenik, I., and Shamsuddin, A. M. (2006). Protection against cancer by dietary IP6 and inositol. Nutr. Cancer 55, 109-125. doi:10.1207/s15327914nc5502_1

Wang, J. D., and Hume, W. R. (1988). Diffusion of hydrogen ion and hydroxyl ion from various sources through dentine. Int. Endod. J. 21, 17-26. doi:10.1111/j. 1365-2591.1988.tb00949.x

Wang, X., Wen, K., Yang, X., Li, L., and Yu, X. (2017). Biocompatibility and anticalcification of a biological artery immobilized with naturally-occurring phytic acid as the crosslinking agent. J. Mater. Chem. B. 5, 8115-8124. doi:10.1039/ c7tb02090b

Weichhold, J., Gbureck, U., Goetz-Neunhoeffer, F., and Hurle, K. (2019). Setting mechanism of a CDHA forming $\alpha$-TCP cement modified with sodium phytate for improved injectability. Materials 12, 2098. doi:10.3390/ma12132098

Xie, Y., Luo, H., Duan, J., Hong, C., Ma, P., Li, G., et al. (2014). Phytic acid enhances the oral absorption of isorhamnetin, quercetin, and kaempferol in total flavones of Hippophae rhamnoides L. Fitoterapia. 93, 216-225. doi:10.1016/j.fitote.2014. 01.013

Xu, J., He, J., Shen, Y., Zhou, X., Huang, D., Gao, Y., et al. (2019). Influence of endodontic procedure on the adherence of Enterococcus faecalis. J. Endod. 45, 943-949. doi:10.1016/j.joen.2019.04.006

Xu, Q., Kanthasamy, A. G., and Reddy, M. B. (2008). Neuroprotective effect of the natural iron chelator, phytic acid in a cell culture model of Parkinson's disease. Toxicology 245, 101-108. doi:10.1016/j.tox.2007.12.017

Yamauchi, N., Nagaoka, H., Yamauchi, S., Teixeira, F. B., Miguez, P., and Yamauchi, M. (2011). Immunohistological characterization of newly formed tissues after regenerative procedure in immature dog teeth. J. Endod. 37, 1636-1641. doi:10.1016/j.joen.2011.08.025

Yao, Y., Grogan, J., Zehnder, M., Lendenmann, U., Nam, B., Wu, Z., et al. (2001). Compositional analysis of human acquired enamel pellicle by mass spectrometry. Arch. Oral Biol. 46, 293-303. doi:10.1016/s0003-9969(00)00134-5

Yoon, J. H., Thompson, L. U., and Jenkins, D. J. (1983). The effect of phytic acid on in vitro rate of starch digestibility and blood glucose response. Am. J. Clin. Nutr. 38, 835-842. doi:10.1093/ajen/38.6.835

York, J. D., Odom, A. R., Murphy, R., Ives, E. B., and Wente, S. R. (1999). A phospholipase C-dependent inositol polyphosphate kinase pathway required for efficient messenger RNA export. Science 285, 96-100. doi:10.1126/science. 285.5424 .96

Zhang, J., Senger, B., Vautier, D., Picart, C., Schaaf, P., Voegel, J. C., et al. (2005). Natural polyelectrolyte films based on layer-by layer deposition of collagen and hyaluronic acid. Biomaterials 26, 3353-3361. doi:10.1016/j.biomaterials.2004. 08.019

Zhang, X., Chen, Y., Lei, H., Zhao, S., Han, F., Xiang, X., et al. (2016). Phytic acid layer template-assisted deposition of $\mathrm{TiO}_{2}$ film on titanium: surface electronic properties, super-hydrophilicity and bending strength. Mater. Des. 89, 476-484. doi:10.1016/j.matdes.2015.10.026

Zhou, Q. I., Zhao, Y. U., Dang, H., Tang, Y., and Zhang, B. (2019). Antibacterial effects of phytic acid against foodborne pathogens and investigation of its mode of action. J. Food Prot. 82, 826-833. doi:10.4315/0362-028X.JFP-18-418

Zhu, T., Ren, H., Li, A., Liu, B., Cui, C., Dong, Y., et al. (2017). Novel bioactive glass based injectable bone cement with improved osteoinductivity and its in vivo evaluation. Sci. Rep. 7, 3622. doi:10.1038/s41598-017-03207-9

Conflict of Interest: The authors declare that the research was conducted in the absence of any commercial or financial relationships that could be construed as a potential conflict of interest.

Copyright $(2021$ Nassar, Nassar, Maki, Al-Yagoob, Hachim, Senok, Williams and Hiraishi. This is an open-access article distributed under the terms of the Creative Commons Attribution License (CC BY). The use, distribution or reproduction in other forums is permitted, provided the original author(s) and the copyright owner(s) are credited and that the original publication in this journal is cited, in accordance with accepted academic practice. No use, distribution or reproduction is permitted which does not comply with these terms. 